\title{
Article \\ Color-Tunable Indolizine-Based Fluorophores and Fluorescent pH Sensor
}

\author{
Taegwan $\operatorname{Kim}^{1}$ and Jonghoon $\operatorname{Kim}^{1,2, *(D)}$ \\ 1 Department of Chemistry, Soongsil University, Seoul 06978, Korea; lever19786@soongsil.ac.kr \\ 2 Integrative Institute of Basic Science, Soongsil University, Seoul 06978, Korea \\ * Correspondence: jhkim19@ssu.ac.kr
}

Citation: Kim, T.; Kim, J.

Color-Tunable Indolizine-Based

Fluorophores and Fluorescent $\mathrm{pH}$

Sensor. Molecules 2022, 27, 12 .

https://doi.org/10.3390/

molecules 27010012

Academic Editor: Barbara Panunzi

Received: 3 December 2021

Accepted: 20 December 2021

Published: 21 December 2021

Publisher's Note: MDPI stays neutral with regard to jurisdictional claims in published maps and institutional affiliations.

Copyright: (c) 2021 by the authors Licensee MDPI, Basel, Switzerland. This article is an open access article distributed under the terms and conditions of the Creative Commons Attribution (CC BY) license (https:/ / creativecommons.org/licenses/by/ $4.0 /)$.

\begin{abstract}
A new fluorescent indolizine-based scaffold was developed using a straightforward synthetic scheme starting from a pyrrole ring. In this fluorescent system, an $N, N$-dimethylamino group in the aryl ring at the $\mathrm{C}-3$ position of indolizine acted as an electron donor and played a crucial role in inducing a red shift in the emission wavelength based on the ICT process. Moreover, various electron-withdrawing groups, such as acetyl and aldehyde, were introduced at the C-7 position of indolizine, to tune and promote the red shift of the emission wavelength, resulting in a color range from blue to orange $(462-580 \mathrm{~nm})$. Furthermore, the ICT effect in indolizine fluorophores allowed the design and development of new fluorescent $\mathrm{pH}$ sensors of great potential in the field of fluorescence bioimaging and sensors.
\end{abstract}

Keywords: indolizine; fluorescence; fluorophore design; $\mathrm{pH}$ sensor; intramolecular charge transfer (ICT)

\section{Introduction}

Optical fluorescence imaging for the non-invasive study of living systems has contributed to the organic fluorophore and fluorescent probe exploitation in the fields of life sciences, medicine, chemical biology, and biotechnology [1-8]. Due to a high demand for the development of novel fluorescent core skeletons, considerable progress has been made over the past few decades, which has resulted in the synthesis of various new fluorophores characterized by specific photophysical properties allowing the development of novel fluorescent probes [9-13]. As an example, indolizine-based organic molecules were successfully exploited in new fluorophores and fluorescent probes [14-20]. Synthetic methods for various types of indolizine scaffolds have led to the development of welldefined fluorophore scaffolds with an in-depth studied structure-fluorescence relationship. Figure 1a reports an emission-tunable and predictable indolizine-based fluorescent core skeleton, 9-aryl-1,2-dihydropyrrolo[3,4-b]indolizin-3-one, named Seoul-Fluor, and various fluorescent probes developed by Park et al. Perturbation of the electron density of the substituents at the C-7 and C-9 positions in Seoul-Fluor dramatically changed the emission wavelength, allowing a systematic tuning of the emission in the range 420-613 nm [21-23]. Moreover, computational studies provided guidelines for tuning the emission wavelength of Seoul-Fluor and developing Seoul-Fluor analogs with improved molar absorptivity [24]. More recently, Kim et al. prepared a new colorful fluorescent scaffold, named Kaleidolizine $(\mathrm{KIz})$, with unique aggregation-induced emission (AIE) properties, on which the resulting fluorogenic probes were based $[25,26]$. However, previous studies typically focused on the synthesis of indolizine via the cycloaddition reaction of pyridinium ylide with alkenes or alkynes, with results critically influenced by the substrates [27-29]. Thus, most of these reactions are limited by incorporation of various functional groups at specific indolizine positions [30]. To address this, substantial efforts have been devoted to the development of straightforward synthetic methods for the incorporation of functional groups into indolizine. An indolizine-based full-color-tunable (405-616 nm) fluorophore, 
named C3-Indo-Fluoro, was developed by Lan et al. through the metal catalytic $\mathrm{C}-\mathrm{H}$ activation of indolizine [31]. Despite the notable advances in indolizine-based fluorophores, the development of a straightforward synthetic strategy for the versatile functionalization of the indolizine core, providing convenient access to new indolizine fluorophores with unique photophysical properties, is challenging. To this end, we conceived a new synthetic route to prepare 3,7-disubstitued indolizine from the pyrrole ring (Figure 1b). The methodology reported in this study revealed a systematic tunability of the emission wavelength (462-580 nm) through the perturbation of the substituent electron density based on the intramolecular charge transfer (ICT) process [32]. Finally, the introduction of a $\mathrm{pH}$-sensitive functional group into this new indolizine-based fluorescent scaffold allowed the successful development of a fluorescent $\mathrm{pH}$ sensor.

(a)

(b)
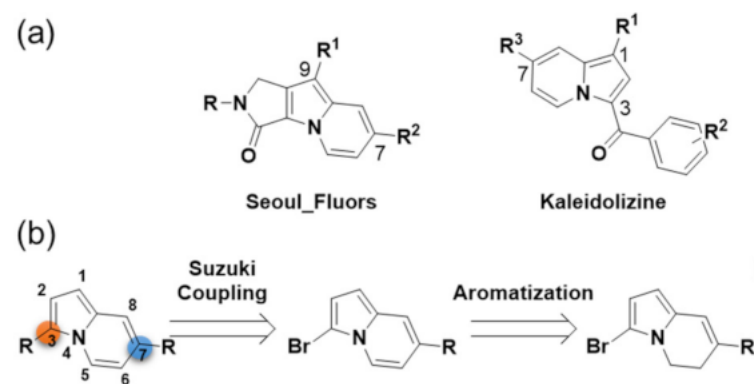

(a)

Figure 1. (a) Indolizine-based fluorescent core skeletons. (b) Retrosynthetic analysis for the 3,7disubstituted new indolizine-based fluorescent skeletons under investigation.

\section{Results and Discussion}

Based on the retrosynthetic analysis, the synthetic pathway employed to provide 3,7-disubstitued indolizine compounds is illustrated in Scheme 1. First, the SN2 reaction of $1 \mathrm{H}$-pyrrole-2-carboxaldehyde (1) with ethyl 4-bromobutyrate afforded compound 2, followed by aldol condensation using sodium hydride $(\mathrm{NaH})$, resulting in the cyclic compound 3. Regioselective bromination of compound 3 with $\mathrm{N}$-bromosuccinimide (NBS) generated compound 4. Afterwards, the dehydrogenative oxidation with manganese dioxide $\left(\mathrm{MnO}_{2}\right)$ generated the indolizine compound 5 with bromo and ester functional groups at the C-3 and C-7 positions, respectively, which allow facile conversion into other functional groups. Finally, to introduce an aryl moiety into the $\mathrm{C}-3$ position for the new $\pi$-conjugated indolizine, we adopted the Suzuki cross-coupling reaction. The optimized cross-coupling conditions were conventional heating in water in the presence of palladium(II) acetate $\left(\mathrm{Pd}(\mathrm{OAc})_{2}\right)$ and tetrabutylammonium bromide (TBAB) without any organic co-solvents [33]. Under the optimized reaction conditions, we successfully prepared a series of 7-aryl substituted indolizine-based fluorescent compounds with various $\mathrm{R}^{1}$ substituents to change the electronic characteristics of the phenyl ring. 
(a)
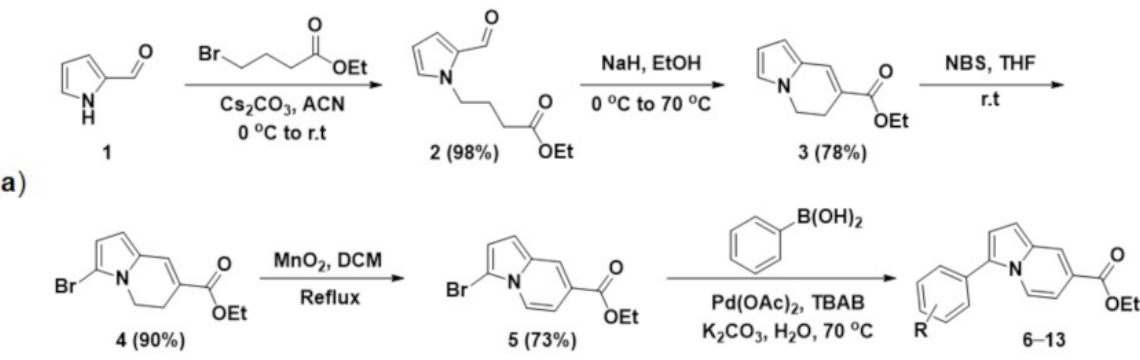

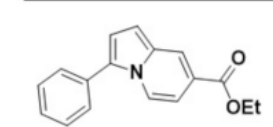

(b)

$6(82 \%)$

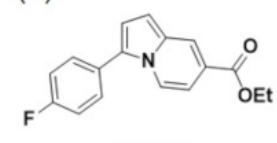

$10(84 \%)$
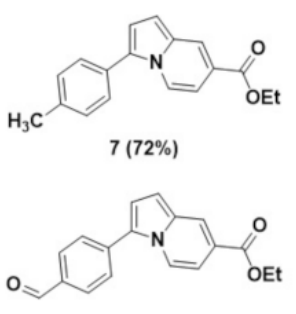

$11(63 \%)$
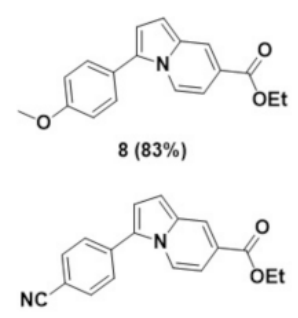

$12(66 \%)$
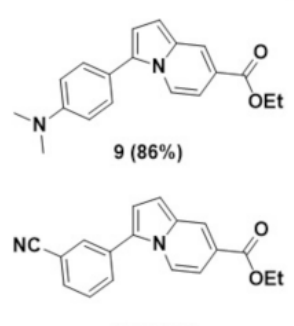

$13(54 \%)$

Scheme 1. (a) Synthetic scheme of 3,7-disubstitued indolizine scaffolds and (b) list of synthesized indolizine-based new fluorescent compounds 6-13.

Our systematic evaluation of the structure-photophysical property relationship included the maximum absorption and emission wavelengths, Stokes shifts, and quantum yields measurements (Table 1). Normalized absorption and emission spectra of each compound are shown in Figure S1 in Supplementary Materials. Interestingly, for all the functional groups introduced at the $\mathrm{R}^{1}$ position (from an electron-donating group, EDG, such as the methoxy group, to an electron-withdrawing group, EWG, such as the cyano group), the maximum absorption and emission wavelength change was negligible. However, compound 9 bearing an $\mathrm{N}, \mathrm{N}$-dimethylamino group, which is the most electron-donating group of the series, exhibited a red shift in the emission spectra $(533 \mathrm{~nm})$, compared to other compounds (462-492 nm). We hypothesized that this feature originated from the ICT process between the $\mathrm{N}, \mathrm{N}$-dimethylamino group at the $\mathrm{R}^{1}$ position and the ester group at the C-7 position of indolizine. Contrarily to other donating groups, with the ester group acting as an electron acceptor, in this electron-push-pull $\pi$-conjugated indolizine-based system, the $\mathrm{N}, \mathrm{N}$-dimethylamino group acted as a powerful electron donor, triggering an ICT process. In the electronic push-pull system in fluorescent scaffolds, the effects of the substituent electronic characteristics on the energy gap between the highest occupied molecular orbital (HOMO) and the lowest unoccupied molecular orbital (LUMO) resulted in a red or blue shift in emission [34]. In the case of compound 9, the $\mathrm{N}, \mathrm{N}$-dimethylamino group on the phenyl ring might increase the HOMO energy level, with a minimal effect on the LUMO energy level, causing a red shift of the emission wavelength. Moreover, ICT causes a large change in the excited state dipole moment, promoting a solvent-dependent emission shift [35]. To determine the effect of ICT, we further studied the solvatochromic fluorescence emission change of compound 9. As shown in Figure 2, the solvent polarity had limited effects on the absorption wavelength. Conversely, an increase in solvent polarity induced a bathochromic shift of the emission wavelength from $485 \mathrm{~nm}$ in non-polar diethyl ether to $533 \mathrm{~nm}$ in polar methanol. This positive emission solvatochromism suggested that the ICT process was the dominant mechanism for the red-shift emission of compound 9. 
Table 1. Photophysical properties of 3,7-disubstituted indolizine compounds.

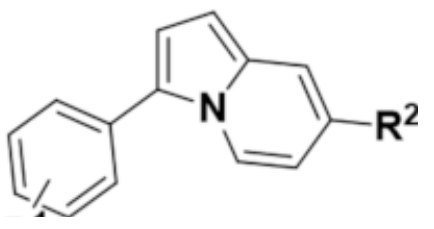

\begin{tabular}{|c|c|c|c|c|c|c|c|}
\hline Cpd & $\mathbf{R}^{1}$ & $\mathbf{R}^{2}$ & $\lambda_{\mathrm{abs}}[\mathrm{nm}]^{[\mathrm{a}]}$ & $\underset{[b]}{\varepsilon\left[\mathbf{M}^{-1} \mathrm{~cm}^{-1}\right]}$ & $\Lambda_{\mathrm{em}}[\mathrm{nm}]^{[\mathrm{c}]}$ & $\underset{[\mathrm{d}]}{\Delta \mathrm{v}\left[\mathrm{cm}^{1}\right]}$ & $\Phi_{\mathrm{F}}^{[\mathrm{e}]}$ \\
\hline 6 & $4-\mathrm{H}$ & $\mathrm{CO}_{2} \mathrm{Et}$ & 389 & 11,000 & 468 & 4399 & 0.24 \\
\hline 7 & $4-\mathrm{CH}_{3}$ & $\mathrm{CO}_{2} \mathrm{Et}$ & 390 & 9550 & 474 & 4544 & 0.26 \\
\hline 8 & 4-OMe & $\mathrm{CO}_{2} \mathrm{Et}$ & 390 & 11,100 & 483 & 4937 & 0.32 \\
\hline 9 & $4-\mathrm{N}(\mathrm{Me})_{2}$ & $\mathrm{CO}_{2} \mathrm{Et}$ & 404 & 10,800 & 533 & 5991 & 0.46 \\
\hline 10 & $4-\mathrm{F}$ & $\mathrm{CO}_{2} \mathrm{Et}$ & 386 & 10,500 & 467 & 4493 & 0.23 \\
\hline 11 & $4-\mathrm{CHO}$ & $\mathrm{CO}_{2} \mathrm{Et}$ & 420 & 18,300 & 492 & 3751 & 0.02 \\
\hline 12 & 4-CN & $\mathrm{CO}_{2} \mathrm{Et}$ & 394 & 17,700 & 466 & 3921 & 0.15 \\
\hline 13 & $3-\mathrm{CN}$ & $\mathrm{CO}_{2} \mathrm{Et}$ & 382 & 12,200 & 462 & 4533 & 0.19 \\
\hline 14 & $4-\mathrm{N}(\mathrm{Me})_{2}$ & $\mathrm{CO}_{2} \mathrm{H}$ & 390 & 8700 & 505 & 5839 & 0.33 \\
\hline 16 & $4-\mathrm{N}(\mathrm{Me})_{2}$ & $\mathrm{CHO}$ & 423 & 15,350 & 580 & 6399 & 0.04 \\
\hline 17 & $4-\mathrm{N}(\mathrm{Me})_{2}$ & $\mathrm{COCH}_{3}$ & 420 & 11,500 & 574 & 6388 & 0.15 \\
\hline
\end{tabular}

All the experimental data were obtained using methanol. ${ }^{\text {[a] }}$ Only the largest absorption maxima are shown. ${ }^{[b]}$ Molar absorption coefficient at maximum absorption wavelength. ${ }^{[c]}$ Excited at the maximum absorption wavelength. ${ }^{[\mathrm{d}]}$ Stokes Shift. ${ }^{[\mathrm{e}]}$ Absolute fluorescence quantum yield.

(a)

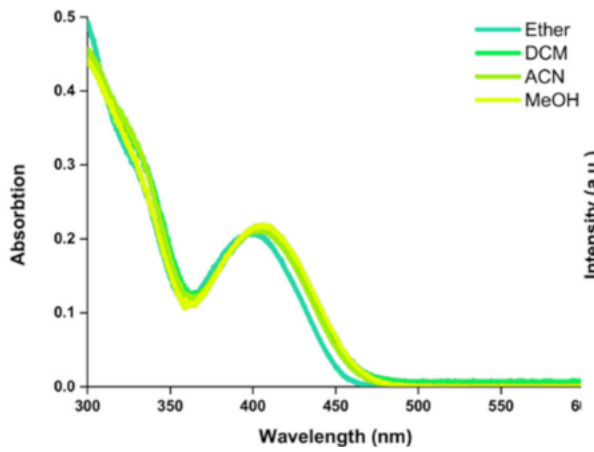

(b)

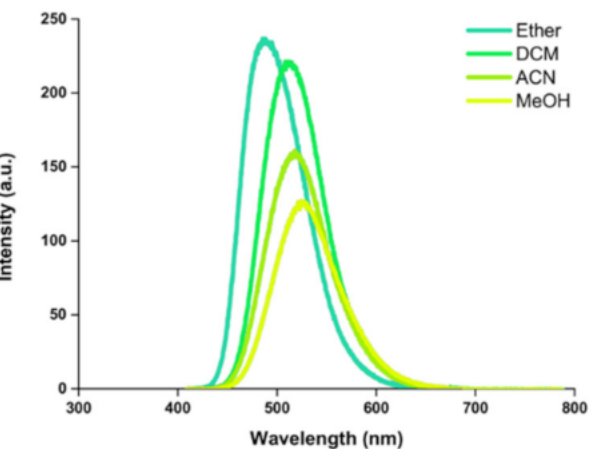

(c)

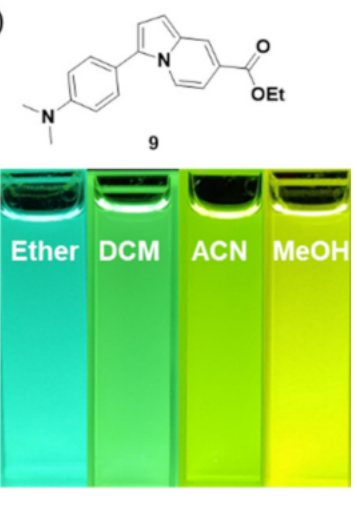

Figure 2. Solvatochromism of compound 9. (a) Absorbance and (b) emission spectra of compound 9 in solvents with different polarity (diethyl ether, DCM, ACN, or MeOH). (c) Fluorescence photo image of compound 9 in different solvents taken under $365 \mathrm{~nm}$ UV light irradiation.

Based on this observation, we designed and synthesized indolizine-based fluorescent compounds to tune the emission wavelength, which can cover a wide range of colors. As the $N, N$-dimethylamino group at the $\mathrm{R}^{1}$ position could successfully reduce the HOMOLUMO energy gap by increasing the HOMO energy level, we hypothesized that the EWG group at the C-7 position influences the stabilization of the LUMO state, allowing a red-shift emission. As shown in Scheme 2, to introduce a stronger electron-withdrawing group than the ester group at the C-7 position, compound 9 was subjected to a hydrolysis reaction in the presence of sodium hydroxide $(\mathrm{NaOH})$, to afford compound 14 . Compound 15 was generated through an amide coupling reaction with $\mathrm{N}, \mathrm{O}$-dimethylhydroxylamine after the activation of carboxylic acids using carbonyldiimidazole (CDI). The $N$-methoxy- $N$-methyl amide group (Weinreb amide) was converted into aldehyde or ketone after treatment with lithium aluminum hydride $\left(\mathrm{LiAlH}_{4}\right)$ or methylmagnesium bromide $\left(\mathrm{CH}_{3} \mathrm{MgBr}\right)$, to produce compounds 16 and 17, respectively. Compounds 16 and 17 bearing aldehyde and acetyl groups, respectively, which are stronger electron-withdrawing groups than ester, 
showed a $47 \mathrm{~nm}$ and $45 \mathrm{~nm}$ red shift of emission wavelength, respectively, compared to compound 9 (Table 1). Nevertheless, the carboxylic acid group at the C-7 position induced a $28 \mathrm{~nm}$ blue shift in emission (Table 1). This was reasonably due to the reduction of the electron-withdrawing strength upon the introduction of the carboxylic acid group at the C-7 position. Figure 3 clearly shows a positive solvatochromism (from 499 to $574 \mathrm{~nm}$ ) and a reduction in fluorescence intensity under polar conditions in compound 17. These more considerable bathochromic shifts and changes in fluorescence intensity compared to compound 9 can be ascribed to the strengthening the ICT process through the introduction of more electron-withdrawing acetyl groups than the ester group at the C-7 position of the indolizine fluorophores. Overall, the synthesized new indolizine fluorophore compounds covered blue to orange-red color emission ranges $(462-580 \mathrm{~nm})$. The normalized emission spectra of representative compounds 12 (blue), 14 (green), 9 (yellow), and 16 (red-orange) are shown in Figure $4 \mathrm{a}$. The colors, brought about irradiation at $365 \mathrm{~nm}$, were visible to the naked eye, as shown in the fluorescence image (Figure $4 b$ ).

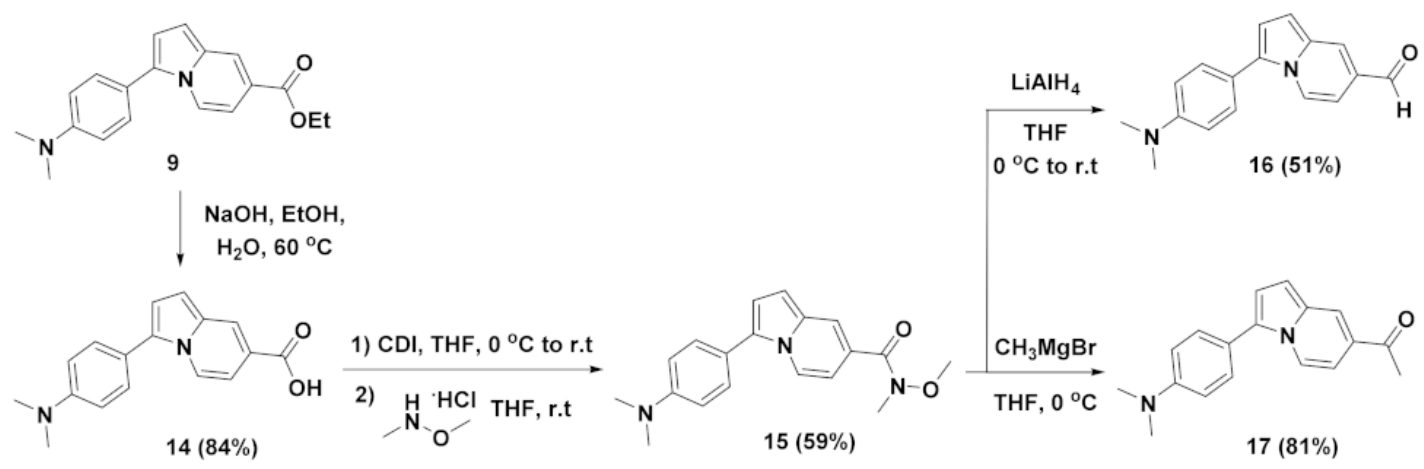

Scheme 2. Synthetic scheme for the modification of ester functional group of compound 9 at the C-7 position.

(a)

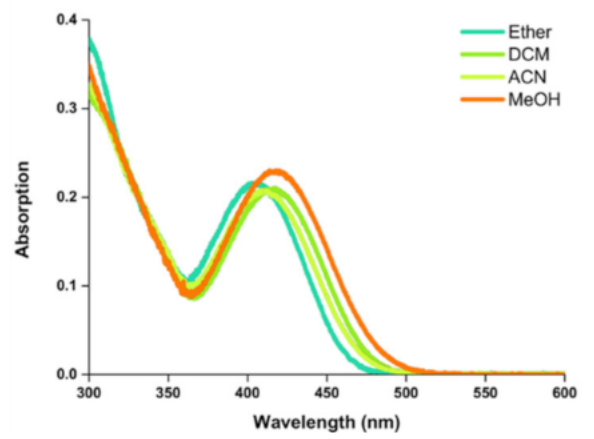

(b)

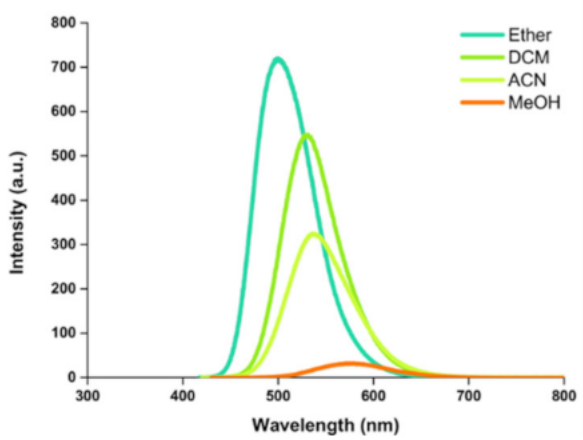

(c)

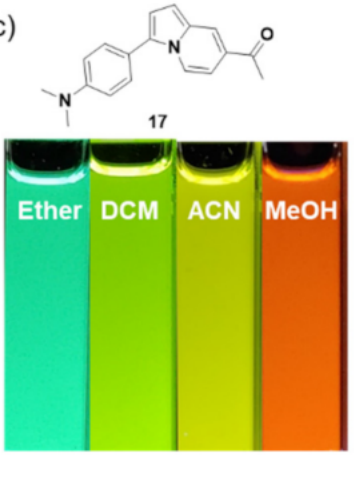

Figure 3. Solvatochromism of compound 17. (a) Absorbance and (b) emission spectra of compound 17 in solvents with different polarity (diethyl ether, DCM, ACN, or MeOH). (c) Fluorescence photo image of compound $\mathbf{1 7}$ in different solvents taken under $365 \mathrm{~nm}$ UV light irradiation. 
(a)

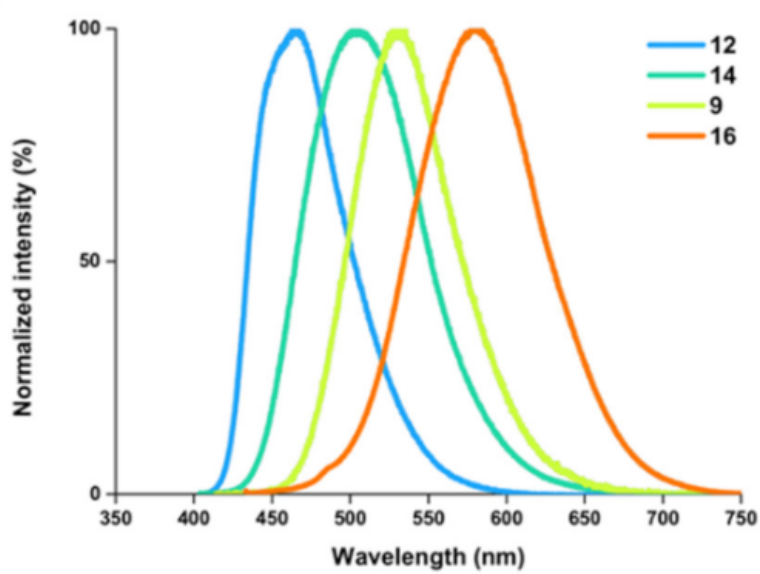

(b)

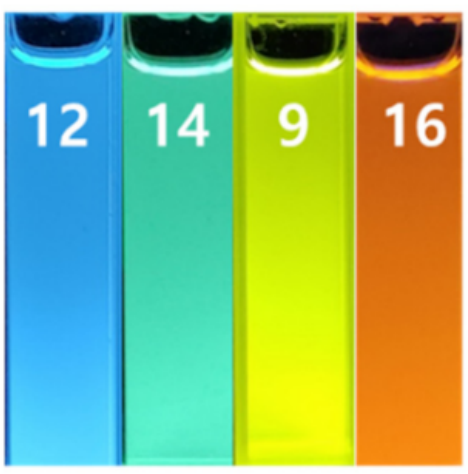

Figure 4. (a) Normalized emission spectra of representative compounds 12 (blue), 14 (green), 9 (yellow), and 16 (red-orange). (b) Fluorescence photo image of each compound in $\mathrm{MeOH}$ taken under $365 \mathrm{~nm}$ UV light irradiation.

Because ICT processes are extensively used in the design of fluorescent probe [36-39], we hypothesized that the unique features of this indolizine-based fluorescent scaffold could lead to new applications for environmental changes as a fluorescent $\mathrm{pH}$ sensor. Therefore, compound $\mathbf{1 4}$ was selected as a potential $\mathrm{pH}$ sensor probe, owing to its $\mathrm{pH}$ responsive functional group, namely the $N, N$-dimethylamino group, at the $\mathrm{R}^{1}$ position and carboxylic acid group at the C-7 position as well as considering high solubility in water solution. The protonation and deprotonation processes of these $\mathrm{pH}$-responsive groups can induce changes in their electronic characteristics according to their $\mathrm{pKa}$ values, generating subsequent dramatic shifts in the emission wavelength. As an example, under acidic conditions, protonation of the dialkylamino group at the $\mathrm{R}^{1}$ position can promote the blue shift of the emission wavelength through the reduction of electron-donating characteristics. Nevertheless, under neutral conditions, the deprotonation of carboxylic acid can reduce the electron-donating character, causing a red-shifted emission. To demonstrate this, the emission response of compound 14 at different $\mathrm{pH}$ values (3.0-7.0) was examined. We observed a blue shift of the emission wavelength from $529 \mathrm{~nm}$ to $473 \mathrm{~nm}$ and an improvement of fluorescence intensity with the $\mathrm{pH}$ decreasing from 7.0 to 3.0 (Figure 5a,b). This result suggested that the protonation and deprotonation of the functional groups on indolizine fluorophores perturbed the electronic states, which could control the ICT process. In neutral conditions, the dimethylamino group could strengthen the ICT process compared to protonated dimethylamino group in acid conditions, leading to a red shift of the emission wavelength and reduction of emission intensity. As shown in Figure 5c, the emission intensity at $473 \mathrm{~nm}$ gradually decreased at higher $\mathrm{pH}$ values, revealing the potential of compound $\mathbf{1 4}$ as a fluorescent $\mathrm{pH}$ sensor. The inflection point of the sigmoid curve for compound 14 was $\mathrm{pH}$ 4.07. Besides compound 14, the emission response of compounds $\mathbf{9}, \mathbf{1 2}, \mathbf{1 6}$, and 17 at different $\mathrm{pH}$ values $(3.0,5.0$, and 7.0$)$ was examined. As expected, compound 9, containing a pH-responsive element such as a dimethylamino group, clearly shows a blue shift of the emission wavelength from $522 \mathrm{~nm}$ to $476 \mathrm{~nm}$ and improvement of fluorescence intensity with the $\mathrm{pH}$ decreasing from 7.0 to 3.0, similar to compound 14. In addition, compounds 16 and 17 exhibit a more dramatic reduction of emission intensity with the $\mathrm{pH}$ increasing from 3.0 to 7.0 compared to compound $\mathbf{9}$, which is caused by strengthening the ICT process through the introduction of a more electronwithdrawing group (aldehyde and acetyl group) at the C-7 position, consistent with the findings in a previous solvatochromic study (Figure $6 c, d$ ). On the other hand, in the case of compound 12 containing cyano group at the $\mathrm{R}^{1}$ position, the emission wavelength and intensity cannot be obviously changed depending on the $\mathrm{pH}$ value, which can be ascribed to less intense ICT through the introduction of an electron-withdrawing group into the 
$\mathrm{R}^{1}$ position (Figure $6 \mathrm{~b}$ ). Thus, we clearly demonstrated that the ICT phenomenon in the indolizine fluorophore allowed the successful development of fluorescent $\mathrm{pH}$ sensors by introducing $\mathrm{pH}$-responsive functional groups such as $\mathrm{N}, \mathrm{N}$-dimethylamino, revealing the potential of this new indolizine fluorophore for versatile fluorescent probes to explore biological systems and environmental changes.

(a)

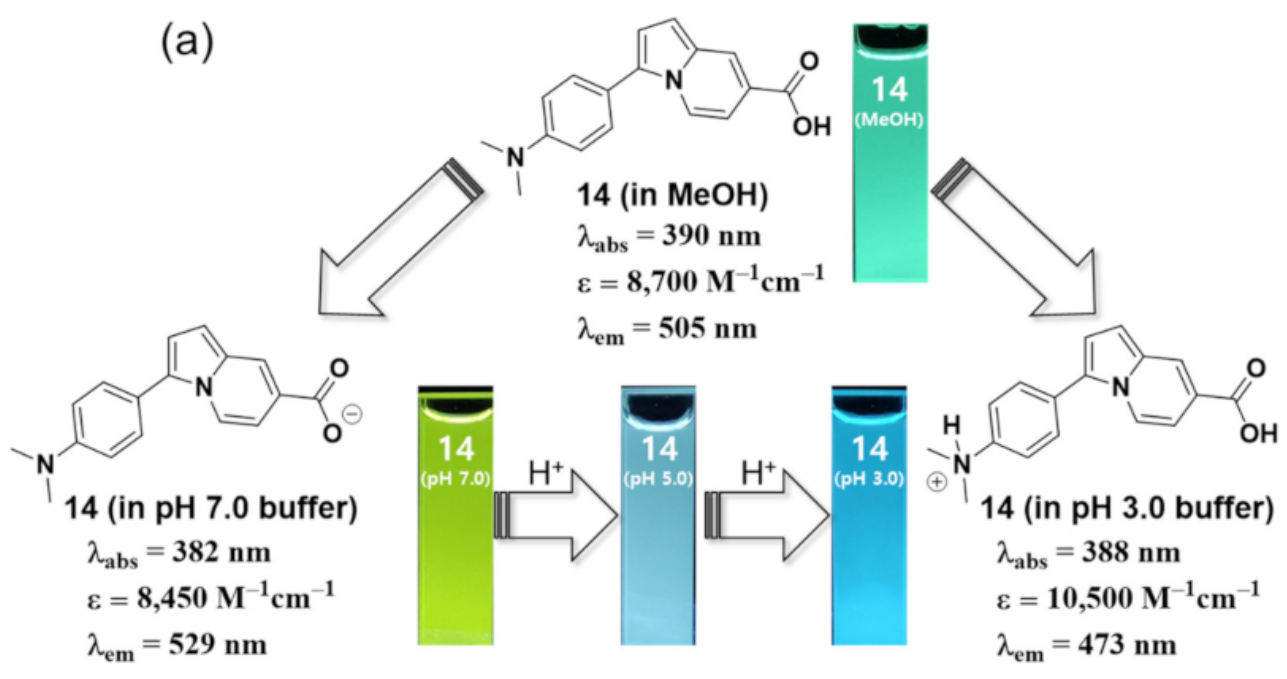

(b)

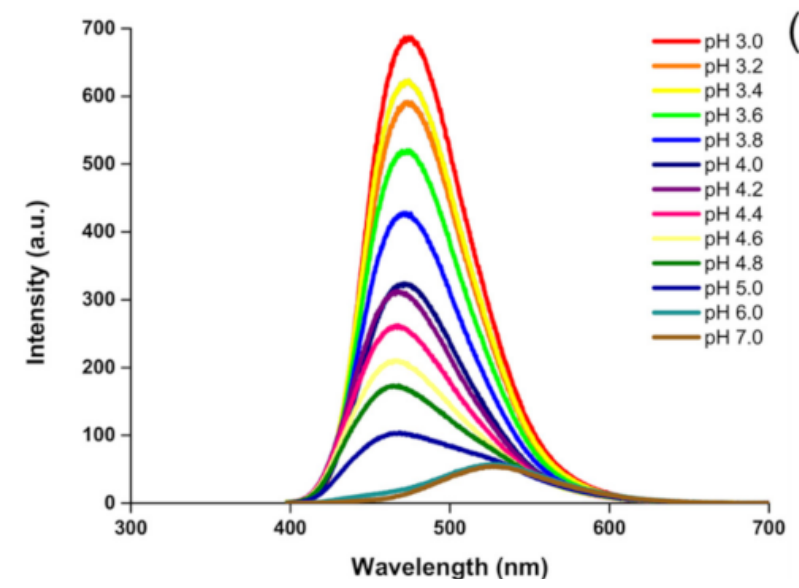

(c)

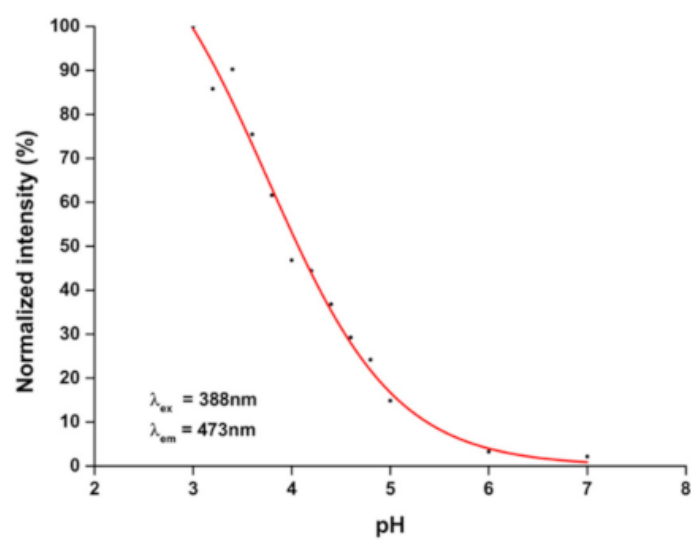

Figure 5. $\mathrm{pH}$ response of compound 14. (a) Photophysical properties and visible color change of compound 14 in $\mathrm{MeOH}, \mathrm{pH}$ 7.0, 5.0, and 3.0 buffer solution. The fluorescence photo images of compound 14 were taken under $365 \mathrm{~nm}$ UV light irradiation. (b) Emission spectra of compound 14 at different $\mathrm{pH}$ buffer solution measured with excitation wavelength at $388 \mathrm{~nm}$. (c) Scatter plots of the normalized fluorescence emission intensity of compound 14 over the $\mathrm{pH}$ range 3-7 with an excitation/emission wavelength at $388 / 473 \mathrm{~nm}$. 
(a)

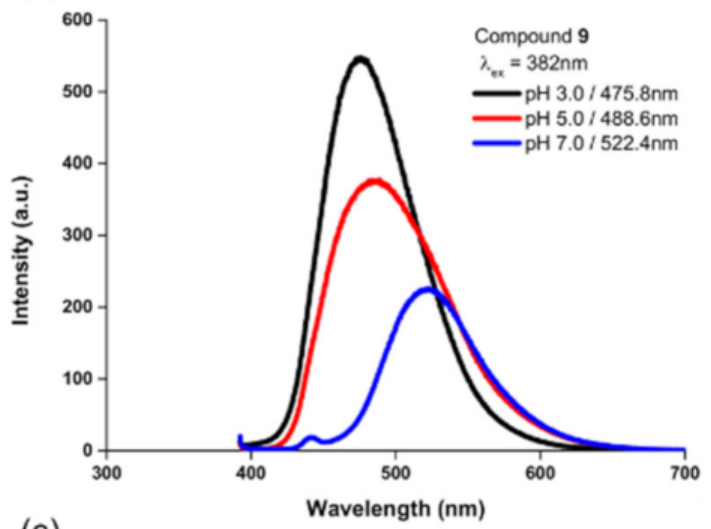

(c)

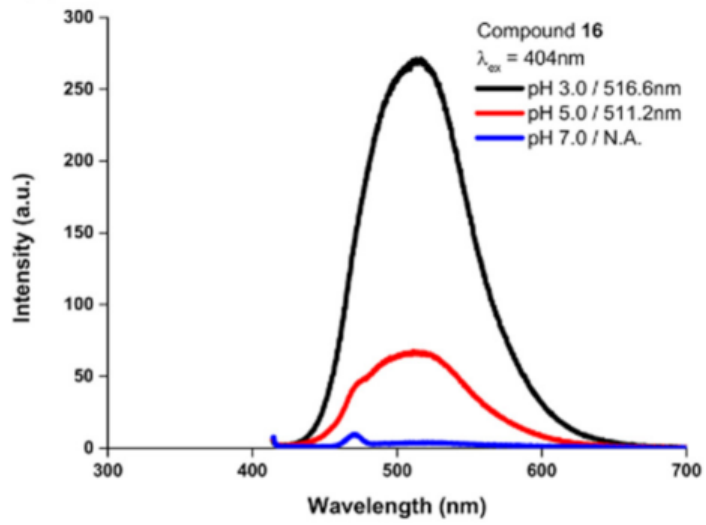

(b)

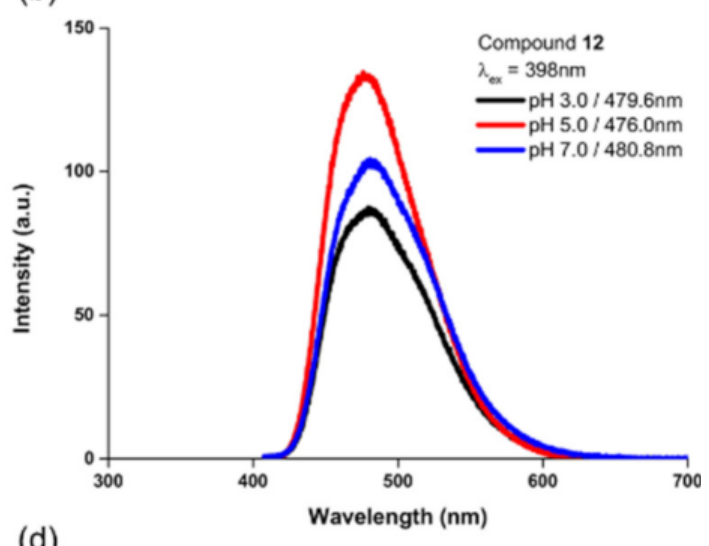

(d)

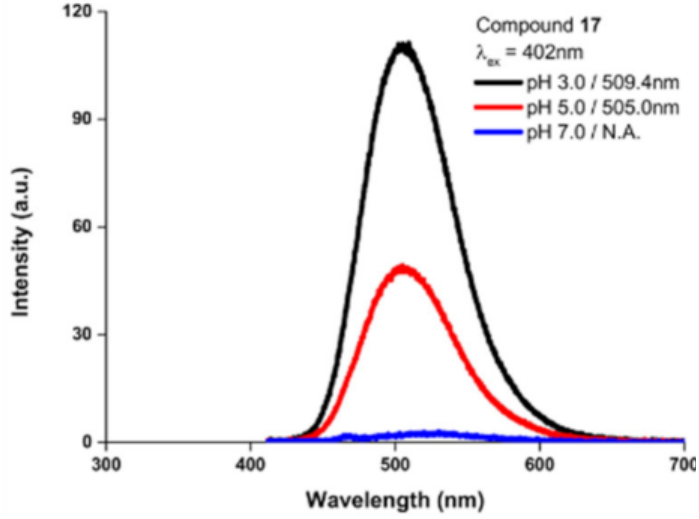

Figure 6. $\mathrm{pH}$ response of compound 9 (a), compound $\mathbf{1 2}(\mathrm{b})$, compound $\mathbf{1 6}(\mathrm{c})$ and compound $\mathbf{1 7}$ (d). Emission spectra of compounds at different $\mathrm{pH}$ buffer solution (3.0, 5.0, and 7.0).

\section{Materials and Methods}

All commercially available reagents were used without further purification unless noted otherwise. Dried solvents were passed through a solvent purification system equipped with activated alumina columns (glass contours). NMR analyses were carried out using a JEOL ECZ500/S1 spectrometer ( $500 \mathrm{MHz}$, Jeol, Tokyo, Japan). The chemical shifts of the proton $\left({ }^{1} \mathrm{H}\right)$ and carbon $\left({ }^{13} \mathrm{C}\right)$ NMR spectra were reported in parts per million $(\delta)$, with respect to the internal standard tetramethylsilane (TMS) or to the residual solvent peak $\left(\mathrm{CDCl}_{3},{ }^{1} \mathrm{H}: 7.26,{ }^{13} \mathrm{C}: 77.00\right.$; DMSO- $d_{6},{ }^{1} \mathrm{H}: 2.49,{ }^{13} \mathrm{C}: 39.52 ; \mathrm{CD}_{2} \mathrm{Cl}_{2},{ }^{1} \mathrm{H}: 5.32,{ }^{13} \mathrm{C}$ : 53.8). The multiplicities of the ${ }^{1} \mathrm{H}$ NMR peaks are reported as follows: $\mathrm{s}$ (singlet), $\mathrm{d}$ (doublet), $\mathrm{t}$ (triplet), q (quartet), quintet, $\mathrm{m}$ (multiplet), dd (doublet of doublets), $\mathrm{dt}$ (doublet of triplets), td (triplet of doublets), and br s (broad singlet). Signals marked with an asterisk $\left.{ }^{*}\right)$ correspond to the peaks assigned to the minor rotamer conformation. The coupling constants $(J)$ were reported in Hz. High-resolution mass spectrometry (HRMS) spectra were obtained on a compact QToF spectrometer (Bruker, Billerica, MA, USA) using the electrospray ionization (ESI) method. Low-resolution mass spectrometry (LRMS) spectra were obtained on a compact mass spectrometer (Advion, Ithaca, NY, USA) using the atmospheric pressure chemical ionization (APCI) method. To monitor the progress of the reactions, analytical thin-layer chromatography (TLC) analysis was performed using glass plates pre-coated with silica gel (60 F254, Merck, Darmstadt, Germany), and the components were observed under UV light (254 and $365 \mathrm{~nm}$ ). Flash column chromatography was performed using silica gel 60 (230-400 mesh, Merck, Darmstadt, Germany). Absorption spectra were recorded using a UV-3101PC spectrophotometer (Shimadzu, Kyoto, Japan) or V-770 spectrophotometer (Jasco, Easton, MD, USA). Fluorescence emission spectra were obtained with a RF-5301PC Fluorescence spectrophotometer (Shimadzu, Kyoto, Japan), and the absolute quantum yield was measured by QE-2000 (Otsuka Electronics, Osaka, Japan). 
Ethyl 4-(2-formyl-1H-pyrrol-1-yl)butanoate (2). To a solution of $1 H$-pyrrole-2-carbaldehyde $(4.33 \mathrm{~g}, 45.5 \mathrm{mmol})$ in acetonitrile $(\mathrm{ACN} ; 230 \mathrm{~mL})$, cesium carbonate $\left(\mathrm{Cs}_{2} \mathrm{CO}_{3} ; 29.6 \mathrm{~g}\right.$, $91.0 \mathrm{mmol}$ ) was added. The reaction mixture was stirred at room temperature (r.t.) for $30 \mathrm{~min}$. Ethyl 4-bromobutyrate $(7.8 \mathrm{~mL}, 54.6 \mathrm{mmol})$ was slowly added to the resultant solution at $0{ }^{\circ} \mathrm{C}$, and the reaction mixture was stirred at r.t. for $18 \mathrm{~h}$. The crude reaction mixture was partitioned into water and ethyl acetate (EtOAc). The aqueous layer was extracted twice with ethyl acetate (EtOAc). The combined organic layers were dried over anhydrous magnesium sulfate $\left(\mathrm{MgSO}_{4}\right)$, filtered, and evaporated. Subsequent silica-gel flash column chromatography afforded ethyl 4-(2-formyl-1H-pyrrol-1-yl)butanoate (2) $\left(9.66 \mathrm{~g}, 44.6 \mathrm{mmol}, 98 \%, R_{f}=0.70(\right.$ EtOAc/hexane $=1: 5)$ as a pale yellow oil. ${ }^{1} \mathrm{H}$ NMR $\left(500 \mathrm{MHz}, \mathrm{CDCl}_{3}\right) \delta(\mathrm{ppm}): 9.52(\mathrm{~d}, J=1.0 \mathrm{~Hz}, 1 \mathrm{H}), 6.94-6.92(\mathrm{~m}, 1 \mathrm{H}), 6.22(\mathrm{dd}, J=4.0$, $3.0 \mathrm{~Hz}, 1 \mathrm{H}), 4.37(\mathrm{t}, J=7.0 \mathrm{~Hz}, 2 \mathrm{H}), 4.12(\mathrm{q}, J=7.0 \mathrm{~Hz}, 2 \mathrm{H}), 2.27(\mathrm{t}, J=7.5 \mathrm{~Hz}, 2 \mathrm{H}), 2.08$ (quintet, $J=7.5 \mathrm{~Hz}, 2 \mathrm{H}), 1.25(\mathrm{t}, J=7.0 \mathrm{~Hz}, 3 \mathrm{H}) .{ }^{13} \mathrm{C} \mathrm{NMR}\left(125 \mathrm{MHz}, \mathrm{CDCl}_{3}\right) \delta(\mathrm{ppm})$ : 179.3, 172.8, 131.5, 131.3, 125.0, 109.7, 60.5, 47.9, 30.8, 26.4, 14.2. LRMS (APCI +): calcd for $\mathrm{C}_{11} \mathrm{H}_{16} \mathrm{NO}_{3}{ }^{+}[\mathrm{M}+\mathrm{H}]^{+}$210.1, found 210.3 .

Ethyl 5,6-dihydroindolizine-7-carboxylate (3). To a solution of compound 2 (1.96 g, $9.35 \mathrm{mmol})$ in ethanol (EtOH; $500 \mathrm{~mL})$, sodium hydride $(\mathrm{NaH} ; 0.41 \mathrm{~g}$ of $60 \%$ dispersion in paraffin liquid, $10.3 \mathrm{mmol}$ ) was added portion-wise at $0{ }^{\circ} \mathrm{C}$. The reaction mixture was stirred at $70{ }^{\circ} \mathrm{C}$ for $18 \mathrm{~h}$ and then cooled to r.t. The resultant mixture was quenched with saturated ammonium chloride $\left(\mathrm{NH}_{4} \mathrm{Cl}\right.$, aq). EtOH was evaporated under reduced pressure, and the crude mixture was partitioned into water and EtOAc. The aqueous layer was extracted twice with EtOAc. The combined layer was dried over anhydrous $\mathrm{MgSO}_{4}$, filtered, and evaporated. Subsequent silica-gel flash column chromatography afforded ethyl 5,6-dihydroindolizine-7carboxylate (3) $\left(1.39 \mathrm{~g}, 7.27 \mathrm{mmol}, 78 \%, R_{f}=0.48(\right.$ EtOAc $/$ hexane $\left.=1: 5)\right)$ as a pale white oil. ${ }^{1} \mathrm{H}$ NMR (500 MHz, $\left.\mathrm{CDCl}_{3}\right) \delta(\mathrm{ppm}): 7.47(\mathrm{~s}, 1 \mathrm{H}), 6.73(\mathrm{t}, J=1.5 \mathrm{~Hz}, 1 \mathrm{H}), 6.35(\mathrm{dd}, J=3.5$, $1.5 \mathrm{~Hz}, 1 \mathrm{H}), 6.21(\mathrm{dd}, J=4.0,3.0 \mathrm{~Hz}, 1 \mathrm{H}), 4.25(\mathrm{q}, J=7.0 \mathrm{~Hz}, 2 \mathrm{H}), 4.01(\mathrm{t}, J=7.0 \mathrm{~Hz}, 2 \mathrm{H})$, $2.80(\mathrm{td}, J=7.5,1.5 \mathrm{~Hz}, 2 \mathrm{H}), 1.33(\mathrm{t}, J=8.5 \mathrm{~Hz}, 3 \mathrm{H}) .{ }^{13} \mathrm{C} \mathrm{NMR}\left(125 \mathrm{MHz}, \mathrm{CDCl}_{3}\right) \delta(\mathrm{ppm})$ : $167.1,128.2,128.0,123.9,119.3,111.8,109.7,60.4,43.9,23.6,14.3$. LRMS (APCI +): calcd for $\mathrm{C}_{11} \mathrm{H}_{14} \mathrm{NO}_{2}{ }^{+}[\mathrm{M}+\mathrm{H}]^{+}$192.1, found 192.3.

Ethyl 3-bromo-5,6-dihydroindolizine-7-carboxylate (4). To a solution of compound 3 (0.50 g, $2.63 \mathrm{mmol}$ ) in tetrahydrofuran (THF; $2.6 \mathrm{~mL}$ ), $N$-bromosuccinimide (NBS; $0.47 \mathrm{~g}, 2.63 \mathrm{mmol}$ ) was added portion-wise at r.t. After the reaction was complete, as indicated by TLC, the reactant was extracted with EtOAc twice, filtered, and evaporated. Subsequent silica-gel flash column chromatography afforded ethyl 3-bromo-5,6-dihydroindolizine-7-carboxylate (4) $\left(0.64 \mathrm{~g}, 2.37 \mathrm{mmol}, 90 \%, R_{f}=0.43(\right.$ EtOAc/hexane $\left.=1: 5)\right)$ as a pale white oil. ${ }^{1} \mathrm{H}$ NMR $\left(500 \mathrm{MHz}, \mathrm{CDCl}_{3}\right) \delta(\mathrm{ppm}): 7.37(\mathrm{t}, J=1.0 \mathrm{~Hz}, 1 \mathrm{H}), 6.33(\mathrm{~d}, J=4.0 \mathrm{~Hz}, 1 \mathrm{H}), 6.22(\mathrm{~d}, J=3.5 \mathrm{~Hz}$, $1 \mathrm{H}), 4.25(\mathrm{q}, J=7.5 \mathrm{~Hz}, 2 \mathrm{H}), 3.97(\mathrm{t}, J=7.5 \mathrm{~Hz}, 2 \mathrm{H}), 2.80(\mathrm{td}, J=7.5,1.5 \mathrm{~Hz}, 2 \mathrm{H}), 1.33(\mathrm{t}$, $J=7.0 \mathrm{~Hz}, 3 \mathrm{H}) .{ }^{13} \mathrm{C} \mathrm{NMR}\left(125 \mathrm{MHz}, \mathrm{CDCl}_{3}\right) \delta(\mathrm{ppm}): 166.9,129.6,127.2,119.5,112.6,112.2$, 106.7, 60.5, 42.5, 23.2, 14.4. LRMS (APCI +): calcd for $\mathrm{C}_{11} \mathrm{H}_{13} \mathrm{BrNO}_{2}{ }^{+}[\mathrm{M}+\mathrm{H}]^{+}$270.0, found 270.2 .

Ethyl 3-bromoindolizine-7-carboxylate (5). To a solution of compound $4(0.71 \mathrm{~g}, 3.0 \mathrm{mmol})$ in dichloromethane (DCM; $150 \mathrm{~mL})$ manganese dioxide $\left(\mathrm{MnO}_{2} ; 13.0 \mathrm{~g}, 150 \mathrm{mmol}\right)$ was added. The reaction mixture was stirred under reflux for $18 \mathrm{~h}$ and then cooled to r.t. The mixture was filtered through Celite and solvent was evaporated. Subsequent silica-gel flash column chromatography afforded ethyl 3-bromoindolizine-7-carboxylate (5) (0.59 g, $2.20 \mathrm{mmol}$, $73 \%, R_{f}=0.46($ EtOAc/hexane $\left.=1: 6)\right)$ as a pale-yellow solid. ${ }^{1} \mathrm{H} \mathrm{NMR}\left(500 \mathrm{MHz}, \mathrm{CDCl}_{3}\right) \delta$ (ppm): $8.17(\mathrm{~s}, 1 \mathrm{H}), 7.94(\mathrm{~d}, J=7.5 \mathrm{~Hz}, 1 \mathrm{H}), 7.21(\mathrm{dd}, J=7.5,2.0 \mathrm{~Hz}, 1 \mathrm{H}), 6.90(\mathrm{~d}, J=4.5 \mathrm{~Hz}$, $1 \mathrm{H}), 6.77(\mathrm{~d}, J=4.0 \mathrm{~Hz}, 1 \mathrm{H}), 4.38(\mathrm{q}, J=7.5 \mathrm{~Hz}, 2 \mathrm{H}), 1.41(\mathrm{t}, J=7.5 \mathrm{~Hz}, 3 \mathrm{H}) .{ }^{13} \mathrm{C} \mathrm{NMR}$ $\left(125 \mathrm{MHz}_{\mathrm{CDCl}}\right.$ ) $\delta$ (ppm): 165.8, 132.4, 122.7, 122.1, 118.7, 117.5, 110.4, 105.3, 96.1, 61.0, 14.4. LRMS (APCI +): calcd for $\mathrm{C}_{11} \mathrm{H}_{11} \mathrm{BrNO}_{2}{ }^{+}[\mathrm{M}+\mathrm{H}]^{+}$268.0, found 268.2.

Ethyl 3-phenylindolizine-7-carboxylate (6). To a solution of compound $5(0.27 \mathrm{~g}, 1.0 \mathrm{mmol})$ in water $(3 \mathrm{~mL})$, phenyl boronic acid $(0.13 \mathrm{~g}, 1.1 \mathrm{mmol})$, potassium carbonate $\left(\mathrm{K}_{2} \mathrm{CO}_{3} ; 0.35 \mathrm{~g}\right.$, 
$2.5 \mathrm{mmol}$ ), tetrabutylammonium bromide (TBAB; $0.32 \mathrm{~g}, 1.0 \mathrm{mmol}$ ), and palladium(II) diacetate $\left(\mathrm{Pd}(\mathrm{OAc})_{2} ; 4 \mathrm{mg}, 0.02 \mathrm{mmol}\right)$ were added. The reaction mixture was stirred at $70{ }^{\circ} \mathrm{C}$ for $2 \mathrm{~h}$. The crude mixture was extracted twice with EtOAc. The combined organic layers were dried over anhydrous $\mathrm{MgSO}_{4}$, filtered, and evaporated. Subsequent silica-gel flash column chromatography afforded ethyl 3-phenylindolizine-7-carboxylate (6) $(0.22 \mathrm{~g}$, $0.82 \mathrm{mmol}, 82 \%, R_{f}=0.43($ EtOAc/hexane $\left.=1: 6)\right)$ as a yellow oil. ${ }^{1} \mathrm{H}$ NMR $(500 \mathrm{MHz}$, $\left.\mathrm{CDCl}_{3}\right) \delta(\mathrm{ppm}): 8.24(\mathrm{~s}, 1 \mathrm{H}), 8.23(\mathrm{dt}, J=7.5,0.5 \mathrm{~Hz}, 1 \mathrm{H}), 7.58(\mathrm{dd}, J=8.5,1.5 \mathrm{~Hz}, 2 \mathrm{H})$, $7.50(\mathrm{t}, J=7.5 \mathrm{~Hz}, 2 \mathrm{H}), 7.39(\mathrm{tt}, J=7.0,1.5 \mathrm{~Hz}, 1 \mathrm{H}), 7.07(\mathrm{dd}, J=7.5,1.5 \mathrm{~Hz}, 1 \mathrm{H}), 6.96(\mathrm{~d}$, $J=4.0 \mathrm{~Hz}, 1 \mathrm{H}), 6.83(\mathrm{~d}, J=4.5 \mathrm{~Hz}, 1 \mathrm{H}), 4.38(\mathrm{q}, J=7.5 \mathrm{~Hz}, 2 \mathrm{H}), 1.41(\mathrm{t}, J=7.0 \mathrm{~Hz}, 3 \mathrm{H}) .{ }^{13} \mathrm{C}$ NMR (125 MHz, $\mathrm{CD}_{2} \mathrm{Cl}_{2}$ ) $\delta$ (ppm): 166.1, 133.0, 132.1, 129.4, 128.5, 128.4, 128.1, 123.5, 121.8, $118.9,116.2,110.0,105.6,61.1,14.5$. HRMS (ESI +): calcd for $\mathrm{C}_{17} \mathrm{H}_{15} \mathrm{NO}_{2} \mathrm{Na}^{+}[\mathrm{M}+\mathrm{Na}]^{+}$ 288.1000, found 288.0995 .

Ethyl 3-(p-tolyl)indolizine-7-carboxylate (7). To a solution of compound $5(0.27 \mathrm{~g}, 1.0 \mathrm{mmol})$ in water $(3 \mathrm{~mL})$, p-tolylboronic acid $(0.15 \mathrm{~g}, 1.1 \mathrm{mmol}), \mathrm{K}_{2} \mathrm{CO}_{3}(0.35 \mathrm{~g}, 2.5 \mathrm{mmol})$, TBAB $(0.32 \mathrm{~g}, 1.0 \mathrm{mmol})$, and $\mathrm{Pd}(\mathrm{OAc})_{2}(4 \mathrm{mg}, 0.02 \mathrm{mmol})$ were added. The reaction mixture was stirred at $70{ }^{\circ} \mathrm{C}$ for $2 \mathrm{~h}$. The crude mixture was extracted twice with EtOAc. The combined organic layers were dried over anhydrous $\mathrm{MgSO}_{4}$, filtered, and evaporated. Subsequent silica-gel flash column chromatography afforded ethyl 3-( $p$-tolyl)indolizine-7-carboxylate (7) $\left(0.27 \mathrm{~g}, 0.95 \mathrm{mmol}, 95 \%, R_{f}=0.43(\right.$ EtOAc/hexane $\left.=1: 6)\right)$ as a yellow oil. ${ }^{1} \mathrm{H}$ NMR $\left(500 \mathrm{MHz}, \mathrm{CDCl}_{3}\right) \delta(\mathrm{ppm}): 8.24(\mathrm{~s}, 1 \mathrm{H}), 8.19(\mathrm{dt}, J=7.5,1.0 \mathrm{~Hz}, 1 \mathrm{H}), 7.47(\mathrm{~d}, J=8.0 \mathrm{~Hz}$, $2 \mathrm{H}), 7.31(\mathrm{~d}, J=8.0 \mathrm{~Hz}, 2 \mathrm{H}), 7.05(\mathrm{dd}, J=7.5,2.0 \mathrm{~Hz}, 1 \mathrm{H}), 6.93(\mathrm{~d}, J=4.0 \mathrm{~Hz}, 1 \mathrm{H}), 6.81$ $(\mathrm{d}, J=3.5 \mathrm{~Hz}, 1 \mathrm{H}), 4.38(\mathrm{q}, J=7.0 \mathrm{~Hz}, 2 \mathrm{H}), 2.43(\mathrm{~s}, 3 \mathrm{H}), 1.41(\mathrm{t}, J=7.0 \mathrm{~Hz}, 3 \mathrm{H}) .{ }^{13} \mathrm{C}$ NMR $\left(125 \mathrm{MHz}, \mathrm{CDCl}_{3}\right) \delta$ (ppm): 166.1, 137.7, 132.3, 129.7, 128.8, 128.2, 128.1, 123.5, 121.4, 118.2, $115.7,109.7,105.2,60.8,21.3,14.4$. HRMS $(E S I+)$ : calcd for $\mathrm{C}_{18} \mathrm{H}_{17} \mathrm{NO}_{2} \mathrm{Na}^{+}[\mathrm{M}+\mathrm{Na}]^{+}$ 302.1157, found 302.1151 .

Ethyl 3-(4-methoxyphenyl)indolizine-7-carboxylate (8). To a solution of compound 5 ( $0.27 \mathrm{~g}$, $1.0 \mathrm{mmol})$ in water $(3 \mathrm{~mL})$, (4-methoxyphenyl)boronic acid $(0.17 \mathrm{~g}, 1.1 \mathrm{mmol}), \mathrm{K}_{2} \mathrm{CO}_{3}$ $(0.35 \mathrm{~g}, 2.5 \mathrm{mmol}), \mathrm{TBAB}(0.32 \mathrm{~g}, 1.0 \mathrm{mmol})$, and $\mathrm{Pd}(\mathrm{OAc})_{2}(4 \mathrm{mg}, 0.02 \mathrm{mmol})$ were added. The reaction mixture was stirred at $70{ }^{\circ} \mathrm{C}$ for $2 \mathrm{~h}$. The crude mixture was extracted twice with EtOAc. The combined organic layers were dried over anhydrous $\mathrm{MgSO}_{4}$, filtered, and evaporated. Subsequent silica-gel flash column chromatography afforded ethyl 3-(4-methoxyphenyl)indolizine-7-carboxylate (8) $\left(0.25 \mathrm{~g}, 0.83 \mathrm{mmol}, 83 \%, R_{f}=0.25\right.$ $($ EtOAc/hexane $=1: 6)$ ) as a yellow solid. ${ }^{1} \mathrm{H}$ NMR $\left(500 \mathrm{MHz}, \mathrm{CDCl}_{3}\right) \delta(\mathrm{ppm}): 8.23(\mathrm{~s}, 1 \mathrm{H})$, $8.14(\mathrm{~d}, J=7.5 \mathrm{~Hz}, 1 \mathrm{H}), 7.49(\mathrm{~d}, J=8.5 \mathrm{~Hz}, 2 \mathrm{H}), 7.06-7.03(\mathrm{~m}, 3 \mathrm{H}), 6.89(\mathrm{~d}, J=4.5 \mathrm{~Hz}, 1 \mathrm{H})$, $6.81(\mathrm{~d}, J=4.0 \mathrm{~Hz}, 1 \mathrm{H}), 4.37(\mathrm{q}, J=7.0 \mathrm{~Hz}, 2 \mathrm{H}), 3.88(\mathrm{~s}, 3 \mathrm{H}), 1.41(\mathrm{t}, J=7.5 \mathrm{~Hz}, 3 \mathrm{H}) .{ }^{13} \mathrm{C}$ NMR (125 MHz, $\left.\mathrm{CDCl}_{3}\right) \delta(\mathrm{ppm}): 166.1,159.2,132.1,129.6,128.0,124.1,123.4,121.2,118.0$, $115.5,114.5,109.6,105.1,60.8,55.4,14.4$. HRMS $\left(\right.$ ESI + ): calcd for $\mathrm{C}_{18} \mathrm{H}_{17} \mathrm{NO}_{3} \mathrm{Na}^{+}[\mathrm{M}+\mathrm{Na}]^{+}$ 318.1106 , found 318.1101 .

Ethyl 3-(4-(dimethylamino)phenyl)indolizine-7-carboxylate (9). To a solution of compound $5(0.27 \mathrm{~g}, 1.0 \mathrm{mmol})$ in water $(3 \mathrm{~mL})$, (4-(dimethylamino)phenyl)boronic acid $(0.18 \mathrm{~g}$, $1.1 \mathrm{mmol}), \mathrm{K}_{2} \mathrm{CO}_{3}(0.35 \mathrm{~g}, 2.5 \mathrm{mmol}), \mathrm{TBAB}(0.32 \mathrm{~g}, 1.0 \mathrm{mmol})$, and $\mathrm{Pd}(\mathrm{OAc})_{2}(4 \mathrm{mg}$, $0.02 \mathrm{mmol}$ ) were added. The reaction mixture was stirred at $70^{\circ} \mathrm{C}$ for $2 \mathrm{~h}$. The crude mixture was extracted twice with EtOAc. The combined organic layers were dried over anhydrous $\mathrm{MgSO}_{4}$, filtered, and evaporated. Subsequent silica-gel flash column chromatography afforded ethyl 3-(4-(dimethylamino)phenyl)indolizine-7-carboxylate (9) $(0.24 \mathrm{~g}, 0.77 \mathrm{mmol}$, $77 \%, R_{f}=0.25($ EtOAc/hexane $\left.=1: 6)\right)$ as a yellow solid. ${ }^{1} \mathrm{H} \mathrm{NMR}\left(500 \mathrm{MHz}, \mathrm{CDCl}_{3}\right) \delta(\mathrm{ppm})$ : $8.22(\mathrm{~s}, 1 \mathrm{H}), 8.17(\mathrm{~d}, J=7.5 \mathrm{~Hz}, 1 \mathrm{H}), 7.44(\mathrm{~d}, J=9.0 \mathrm{~Hz}, 2 \mathrm{H}), 7.02(\mathrm{dd}, J=7.5,2.0 \mathrm{~Hz}, 1 \mathrm{H})$, $6.87(\mathrm{~d}, J=4.0 \mathrm{~Hz}, 1 \mathrm{H}), 6.84(\mathrm{~d}, J=9.0 \mathrm{~Hz}, 2 \mathrm{H}), 6.80(\mathrm{~d}, J=4.0 \mathrm{~Hz}, 1 \mathrm{H}), 4.37(\mathrm{q}, J=7.5 \mathrm{~Hz}$, $2 \mathrm{H}), 3.03(\mathrm{~s}, 6 \mathrm{H}), 1.41(\mathrm{t}, J=7.5 \mathrm{~Hz}, 3 \mathrm{H}) .{ }^{13} \mathrm{C} \mathrm{NMR}\left(125 \mathrm{MHz}, \mathrm{CDCl}_{3}\right) \delta(\mathrm{ppm}): 166.2,149.9$, 131.8, 129.1, 128.8, 123.4, 121.3, 119.3, 117.4, 115.1, 112.5, 109.3, 105.1, 60.7, 40.4, 14.4. HRMS $(\mathrm{ESI}+)$ : calcd for $\mathrm{C}_{19} \mathrm{H}_{21} \mathrm{~N}_{2} \mathrm{O}_{2}{ }^{+}[\mathrm{M}+\mathrm{H}]^{+}$309.1603, found 309.1598. 
Ethyl 3-(4-fluorophenyl)indolizine-7-carboxylate (10). To a solution of compound 5 (0.27 $\mathrm{g}$, $1.0 \mathrm{mmol})$ in water $(3 \mathrm{~mL})$, (4-fluorophenyl)boronic acid $(0.15 \mathrm{~g}, 1.1 \mathrm{mmol}), \mathrm{K}_{2} \mathrm{CO}_{3}(0.35 \mathrm{~g}$, $2.5 \mathrm{mmol})$, TBAB (0.32 $\mathrm{g}, 1.0 \mathrm{mmol})$, and $\mathrm{Pd}(\mathrm{OAc})_{2}(4 \mathrm{mg}, 0.02 \mathrm{mmol})$ were added. The reaction mixture was stirred at $70{ }^{\circ} \mathrm{C}$ for $2 \mathrm{~h}$. The crude mixture was extracted twice with EtOAc. The combined organic layers were dried over anhydrous $\mathrm{MgSO}_{4}$, filtered, and evaporated. Subsequent silica-gel flash column chromatography afforded ethyl 3-(4-fluorophenyl)indolizine-7-carboxylate (10) $\left(0.24 \mathrm{~g}, 0.84 \mathrm{mmol}, 84 \%, R_{f}=0.43\right.$ $($ EtOAc/hexane $=1: 6)$ ) as a yellow solid. ${ }^{1} \mathrm{H} \mathrm{NMR}\left(500 \mathrm{MHz}, \mathrm{CDCl}_{3}\right) \delta(\mathrm{ppm}): 8.24(\mathrm{~s}$, $1 \mathrm{H}), 8.12(\mathrm{~d}, J=7.5 \mathrm{~Hz}, 1 \mathrm{H}), 7.55-7.51(\mathrm{~m}, 2 \mathrm{H}), 7.20(\mathrm{t}, J=8.5 \mathrm{~Hz}, 2 \mathrm{H}), 7.07(\mathrm{dd}, J=7.5$, $2.0 \mathrm{~Hz}, 1 \mathrm{H}), 6.91(\mathrm{~d}, J=4.0 \mathrm{~Hz}, 1 \mathrm{H}), 6.81(\mathrm{~d}, J=4.0 \mathrm{~Hz}, 1 \mathrm{H}), 4.38(\mathrm{q}, J=7.0 \mathrm{~Hz}, 2 \mathrm{H}), 1.41(\mathrm{t}$, $J=7.0 \mathrm{~Hz}, 3 \mathrm{H}) .{ }^{13} \mathrm{C} \mathrm{NMR}\left(125 \mathrm{MHz}, \mathrm{CDCl}_{3}\right) \delta$ (ppm): 165.9, 163.2, 161.2, 132.4, 130.0, 129.9, $127.8,127.0,123.5,121.1,118.5,116.2,116.0,115.9,109.9,105.2,60.8,14.4$. LRMS(ESI+): calcd for $\mathrm{C}_{17} \mathrm{H}_{15} \mathrm{FNO}_{2}{ }^{+}[\mathrm{M}+\mathrm{H}]^{+}$284.1, found 284.1. HRMS (ESI +): calcd for $\mathrm{C}_{17} \mathrm{H}_{14} \mathrm{FNO}_{2} \mathrm{Na}^{+}$ $[\mathrm{M}+\mathrm{Na}]^{+}$306.0906, found 306.0901.

Ethyl 3-(4-formylphenyl)indolizine-7-carboxylate (11). To a solution of compound 5 (0.27 g, $1.0 \mathrm{mmol})$ in water $(3 \mathrm{~mL})$, (4-formylphenyl)boronic acid $(0.16 \mathrm{~g}, 1.1 \mathrm{mmol}), \mathrm{K}_{2} \mathrm{CO}_{3}(0.35 \mathrm{~g}$, $2.5 \mathrm{mmol}), \operatorname{TBAB}(0.32 \mathrm{~g}, 1.0 \mathrm{mmol})$, and $\mathrm{Pd}(\mathrm{OAc})_{2}(4 \mathrm{mg}, 0.02 \mathrm{mmol})$ were added. The reaction mixture was stirred at $70{ }^{\circ} \mathrm{C}$ for $90 \mathrm{~min}$. The crude mixture was extracted twice with EtOAc. The combined organic layers were dried over anhydrous $\mathrm{MgSO}_{4}$, filtered, and evaporated. Subsequent silica-gel flash column chromatography afforded ethyl 3-(4-formylphenyl)indolizine-7-carboxylate (11) $\left(0.19 \mathrm{~g}, 0.63 \mathrm{mmol}, 63 \%, R_{f}=0.11\right.$ $($ EtOAc/hexane $=1: 6)$ ) as a yellow solid. ${ }^{1} \mathrm{H}$ NMR $\left(500 \mathrm{MHz}, \mathrm{CDCl}_{3}\right) \delta(\mathrm{ppm}): 10.05(\mathrm{~s}, 1 \mathrm{H})$, $8.31(\mathrm{~d}, J=7.5 \mathrm{~Hz}, 1 \mathrm{H}), 8.26(\mathrm{~s}, 1 \mathrm{H}), 8.00(\mathrm{~d}, J=6.5 \mathrm{~Hz}, 2 \mathrm{H}), 7.76(\mathrm{~d}, J=8.0 \mathrm{~Hz}, 2 \mathrm{H}), 7.15$ $(\mathrm{dd}, J=7.5,1.5 \mathrm{~Hz}, 1 \mathrm{H}), 7.07(\mathrm{~d}, J=4.0 \mathrm{~Hz}, 1 \mathrm{H}), 6.85(\mathrm{~d}, J=4.0 \mathrm{~Hz}, 1 \mathrm{H}), 4.39(\mathrm{q}, J=7.5 \mathrm{~Hz}$, 2H), $1.41(\mathrm{t}, J=6.5 \mathrm{~Hz}, 3 \mathrm{H}) .{ }^{13} \mathrm{C} \mathrm{NMR}\left(125 \mathrm{MHz} \mathrm{CDCl}_{3}\right) \delta(\mathrm{ppm}): 191.4,165.7,137.6,134.9$, $133.8,130.6,127.7,126.7,123.5,121.5,119.6,117.2,110.6,106.1,61.0,14.4$. HRMS (ESI +): calcd for $\mathrm{C}_{18} \mathrm{H}_{15} \mathrm{NO}_{3} \mathrm{Na}^{+}[\mathrm{M}+\mathrm{Na}]^{+}$316.0950, found 316.0944.

Ethyl 3-(4-cyanophenyl)indolizine-7-carboxylate (12). To a solution of compound 5 (0.27 g, $1.0 \mathrm{mmol})$ in water $(3 \mathrm{~mL}),\left(4\right.$-cyanophenyl)boronic acid $(0.16 \mathrm{~g}, 1.1 \mathrm{mmol}), \mathrm{K}_{2} \mathrm{CO}_{3}(0.35 \mathrm{~g}$, $2.5 \mathrm{mmol})$, TBAB $(0.32 \mathrm{~g}, 1.0 \mathrm{mmol})$, and $\mathrm{Pd}(\mathrm{OAc})_{2}(4 \mathrm{mg}, 0.02 \mathrm{mmol})$ were added. The reaction mixture was stirred at $70{ }^{\circ} \mathrm{C}$ for $2 \mathrm{~h}$. The crude mixture was extracted twice with EtOAc. The combined organic layers were dried over anhydrous $\mathrm{MgSO}_{4}$, filtered, and evaporated. Subsequent silica-gel flash column chromatography afforded ethyl 3-(4-cyanophenyl)indolizine-7-carboxylate (12) $\left(0.19 \mathrm{~g}, 0.66 \mathrm{mmol}, 66 \%, R_{f}=0.14\right.$ $($ EtOAc/hexane $=1: 6)$ ) as a yellow solid. ${ }^{1} \mathrm{H} \mathrm{NMR}\left(500 \mathrm{MHz}, \mathrm{CDCl}_{3}\right) \delta(\mathrm{ppm}): 8.26-8.25$ $(\mathrm{m}, 2 \mathrm{H}), 7.77(\mathrm{~d}, J=8.5 \mathrm{~Hz}, 2 \mathrm{H}), 7.70(\mathrm{~d}, J=8.5 \mathrm{~Hz}, 2 \mathrm{H}), 7.15(\mathrm{dd}, J=7.5,1.5 \mathrm{~Hz}, 1 \mathrm{H}), 7.03$ $(\mathrm{d}, J=4.5 \mathrm{~Hz}, 1 \mathrm{H}), 6.85(\mathrm{~d}, J=4.5 \mathrm{~Hz}, 1 \mathrm{H}), 4.39(\mathrm{q}, J=7.0 \mathrm{~Hz}, 2 \mathrm{H}), 1.41(\mathrm{t}, J=7.0 \mathrm{~Hz}, 3 \mathrm{H})$. ${ }^{13} \mathrm{C} \mathrm{NMR}\left(125 \mathrm{MHz} \mathrm{CDCl}_{3}\right) \delta$ (ppm): 165.6, 136.2, 133.8, 132.9, 127.8, 126.0, 123.5, 121.3, $119.8,118.7,117.1,110.7,110.6,106.1,61.0,14.3$. HRMS (ESI +): calcd for $\mathrm{C}_{18} \mathrm{H}_{14} \mathrm{~N}_{2} \mathrm{O}_{2} \mathrm{Na}^{+}$ $[\mathrm{M}+\mathrm{Na}]^{+}$313.0953, found 313.0947.

Ethyl 3-(3-cyanophenyl)indolizine-7-carboxylate (13). To a solution of compound 5 (0.27 g, $1.0 \mathrm{mmol})$ in water $(3 \mathrm{~mL}),\left(3\right.$-cyanophenyl)boronic acid $(0.16 \mathrm{~g}, 1.1 \mathrm{mmol}), \mathrm{K}_{2} \mathrm{CO}_{3}(0.35 \mathrm{~g}$, $2.5 \mathrm{mmol}), \mathrm{TBAB}(0.32 \mathrm{~g}, 1.0 \mathrm{mmol})$, and $\mathrm{Pd}(\mathrm{OAc})_{2}(4 \mathrm{mg}, 0.02 \mathrm{mmol})$ were added. The reaction mixture was stirred at $70{ }^{\circ} \mathrm{C}$ for $2 \mathrm{~h}$. The crude mixture was extracted twice with EtOAc. The combined organic layers were dried over anhydrous $\mathrm{MgSO}_{4}$, filtered, and evaporated. Subsequent silica-gel flash column chromatography afforded ethyl 3-(3-cyanophenyl)indolizine-7-carboxylate (13) $\left(0.16 \mathrm{~g}, 0.54 \mathrm{mmol}, 54 \%, R_{f}=0.14\right.$ $($ EtOAc/hexane $=1: 6))$ as a yellow solid. ${ }^{1} \mathrm{H} \mathrm{NMR}\left(500 \mathrm{MHz}, \mathrm{CDCl}_{3}\right) \delta(\mathrm{ppm}): 8.26(\mathrm{~s}, 1 \mathrm{H})$, $8.17(\mathrm{~d}, J=7.0 \mathrm{~Hz}, 1 \mathrm{H}), 7.86(\mathrm{t}, J=1.5 \mathrm{~Hz}, 1 \mathrm{H}), 7.82(\mathrm{dt}, J=7.5,1.5 \mathrm{~Hz}, 1 \mathrm{H}), 7.65(\mathrm{dt}, J=7.5$, $1.5 \mathrm{~Hz}, 1 \mathrm{H}), 7.61(\mathrm{t}, J=8.0 \mathrm{~Hz}, 1 \mathrm{H}), 7.14(\mathrm{dd}, J=7.5,1.5 \mathrm{~Hz}, 1 \mathrm{H}), 6.99(\mathrm{~d}, J=4.0 \mathrm{~Hz}, 1 \mathrm{H})$, $6.84(\mathrm{~d}, J=4.0 \mathrm{~Hz}, 1 \mathrm{H}), 4.39(\mathrm{q}, J=7.0 \mathrm{~Hz}, 2 \mathrm{H}), 1.41(\mathrm{t}, J=7.0 \mathrm{~Hz}, 3 \mathrm{H}) .{ }^{13} \mathrm{C} \mathrm{NMR}(125 \mathrm{MHz}$, $\left.\mathrm{CDCl}_{3}\right) \delta$ (ppm): 165.7, 133.3, 133.1, 131.9, 131.3, 130.8, 130.0, 125.4, 123.5, 120.9, 119.4, 118.4, 
116.6, 113.5, 110.6, 105.7, 61.0, 14.4. HRMS (ESI +): calcd for $\mathrm{C}_{18} \mathrm{H}_{14} \mathrm{~N}_{2} \mathrm{O}_{2} \mathrm{Na}^{+}[\mathrm{M}+\mathrm{Na}]^{+}$ 313.0953, found 313.0947.

3-(4-(Dimethylamino)phenyl)indolizine-7-carboxylic acid (14). To a solution of compound 9 $(0.37 \mathrm{~g}, 1.2 \mathrm{mmol})$ in $\mathrm{EtOH}(4 \mathrm{~mL})$ and water $(2 \mathrm{~mL})$, sodium hydroxide $(\mathrm{NaOH} ; 0.10 \mathrm{~g}$, $2.4 \mathrm{mmol}$ ) was added. The reaction mixture was stirred at $60^{\circ} \mathrm{C}$. After the reaction was complete, as indicated by TLC, the mixture was acidified with $1 \mathrm{~N}$ hydrogen chloride $(\mathrm{HCl} ; \mathrm{aq})$ to give a yellow precipitate. The resulting precipitate was filtered and dried to afford desired product, 3-(4-dimethylamino)phenyl)indolizine-7-carboxylic acid (14) $\left(0.29 \mathrm{~g}, 1.0 \mathrm{mmol}, 84 \%, R_{f}=0.20(\right.$ EtOAc/hexane $\left.=2: 1)\right)$ as a yellow solid. ${ }^{1} \mathrm{H}$ NMR $(500 \mathrm{Mz}$, DMSO- $\left.d_{6}\right) \delta(\mathrm{ppm}): 12.67(\mathrm{br} \mathrm{s}, 1 \mathrm{H}), 8.25(\mathrm{~d}, J=7.5 \mathrm{~Hz}, 1 \mathrm{H}), 8.15(\mathrm{~s}, 1 \mathrm{H}), 7.43(\mathrm{~d}, J=9.0 \mathrm{~Hz}$, $2 \mathrm{H}), 6.96(\mathrm{dd}, J=7.5,1.5 \mathrm{~Hz}, 1 \mathrm{H}), 6.92(\mathrm{~d}, J=4.0 \mathrm{~Hz}, 1 \mathrm{H}), 6.86-6.84(\mathrm{~m}, 3 \mathrm{H}), 2.96(\mathrm{~s}, 6 \mathrm{H}) .{ }^{13} \mathrm{C}$ NMR (125 MHz, $\left.\left.\mathrm{CDCl}_{3}\right)\right) \delta(\mathrm{ppm}): 171.5,150.1,131.8,129.6,129.2,124.9,121.4,119.2,116.1$, 115.5, 112.6, 109.4, 106.2, 40.4. HRMS (ESI +): calcd for $\mathrm{C}_{17} \mathrm{H}_{17} \mathrm{~N}_{2} \mathrm{O}_{2}{ }^{+}[\mathrm{M}+\mathrm{H}]^{+} 281.1290$, found 281.1285 .

3-(4-(Dimethylamino)phenyl)-N-methoxy-N-methylindolizine-7-carboxamide (15). To a solution of compound $14(0.36 \mathrm{~g}, 1.3 \mathrm{mmol})$ in THF $(13 \mathrm{~mL}), 1,1^{\prime}$-carbonyldiimidazole (CDI; $0.25 \mathrm{~g}$, $1.6 \mathrm{mmol}$ ) was added at $0{ }^{\circ} \mathrm{C}$. The reaction mixture was stirred at r.t for $30 \mathrm{~min}$. To the resultant mixture, $\mathrm{N}, \mathrm{O}$-dimethylhydroxylamine hydrochloride $(0.15 \mathrm{~g}, 1.5 \mathrm{mmol})$ was added at r.t and stirred for $18 \mathrm{~h}$. The reaction mixture was partitioned into $1 \mathrm{~N}$ sodium hydroxide $(\mathrm{NaOH} ; \mathrm{aq})$ solution and EtOAc. The aqueous solution was extracted twice with EtOAc. The combined organic solutions were washed with $1 \mathrm{~N} \mathrm{NaOH}$, dried anhydrous $\mathrm{MgSO}_{4}$, filtered, and evaporated. Subsequent silica-gel flash column chromatography afforded 3-(4-(dimethylamino)phenyl)- $\mathrm{N}$-methoxy- $\mathrm{N}$-methylindolizine-7-carboxamide (15) $\left(0.24 \mathrm{~g}, 0.75 \mathrm{mmol}, 59 \%, R_{f}=0.22(\right.$ EtOAc/hexane $\left.=1: 1)\right)$ as an orange oil. ${ }^{1} \mathrm{H}$ NMR $\left(500 \mathrm{MHz}, \mathrm{CDCl}_{3}\right) \delta(\mathrm{ppm}): 8.16(\mathrm{~d}, J=7.5 \mathrm{~Hz}, 1 \mathrm{H}), 8.02(\mathrm{~s}, 1 \mathrm{H}), 7.44(\mathrm{~d}, J=9.0 \mathrm{~Hz}, 2 \mathrm{H}), 6.89$ $(\mathrm{dd}, J=7.5,1.5 \mathrm{~Hz}, 1 \mathrm{H}), 6.86-6.83(\mathrm{~m}, 3 \mathrm{H}), 6.72(\mathrm{~d}, J=4.0,1 \mathrm{H}), 3.64 / 3.62^{*}(\mathrm{~s}, 3 \mathrm{H}), 3.39 / 3.38^{*}$ $(\mathrm{s}, 3 \mathrm{H}), 3.05^{*} / 3.03(\mathrm{~s}, 6 \mathrm{H})$. LRMS (APCI + ): calcd for $\mathrm{C}_{19} \mathrm{H}_{22} \mathrm{~N}_{3} \mathrm{O}_{2}{ }^{+}[\mathrm{M}+\mathrm{H}]^{+} 324.2$, found 324.2.

3-(4-(Dimethylamino)phenyl)indolizine-7-carbaldehyde (16). To a solution of compound 15 $(0.11 \mathrm{~g}, 0.35 \mathrm{mmol})$ in dry THF $(3.5 \mathrm{~mL})$, under an argon atmosphere, a solution of lithium aluminium hydride in THF $\left(\mathrm{LiAlH}_{4} ; 0.2 \mathrm{~mL}, 2.0 \mathrm{M}\right)$ was added dropwise at $0{ }^{\circ} \mathrm{C}$. The reaction mixture was stirred at r.t for $2 \mathrm{~h}$. After the reaction was complete, as indicated by TLC, the mixture was quenched with saturated $\mathrm{NH}_{4} \mathrm{Cl}(\mathrm{aq})$, and then extracted twice with EtOAc. The combined organic layers were dried over anhydrous $\mathrm{MgSO}_{4}$, filtered, and evaporated. Subsequent silica-gel flash column chromatography afforded 3-(4(dimethylamino)phenyl)indolizine-7-carbaldehyde (16) ( $47 \mathrm{mg}, 0.18 \mathrm{mmol}, 51 \%, R_{f}=0.32$ $($ EtOAc/hexane $=1: 5))$ as a yellow solid. ${ }^{1} \mathrm{H}$ NMR $\left(500 \mathrm{MHz}, \mathrm{CDCl}_{3}\right) \delta(\mathrm{ppm}): 9.76(\mathrm{~s}, 1 \mathrm{H})$, $8.18(\mathrm{~d}, J=7.5 \mathrm{~Hz}, 1 \mathrm{H}), 7.90(\mathrm{~s}, 1 \mathrm{H}), 7.44(\mathrm{~d}, J=9.0 \mathrm{~Hz}, 2 \mathrm{H}), 6.98(\mathrm{dd}, J=7.0,1.5 \mathrm{~Hz}, 1 \mathrm{H})$, $6.94(\mathrm{~d}, J=4.0 \mathrm{~Hz}, 1 \mathrm{H}), 6.91(\mathrm{~d}, J=4.5 \mathrm{~Hz}, 1 \mathrm{H}), 6.84(\mathrm{~d}, J=9.0 \mathrm{~Hz}, 2 \mathrm{H}), 3.04(\mathrm{~s}, 6 \mathrm{H}) .{ }^{13} \mathrm{C}$ NMR (125 MHz, $\mathrm{CDCl}_{3}$ ) $\delta$ (ppm): 189.4, 150.2, 131.6, 130.8, 129.2, 128.7, 125.5, 122.3, 118.7, $115.8,112.3,107.7,106.3,40.3$. HRMS (ESI +): calcd for $\mathrm{C}_{17} \mathrm{H}_{17} \mathrm{~N}_{2} \mathrm{O}^{+}[\mathrm{M}+\mathrm{H}]^{+}$265.1341, found 265.1335 .

1-(3-(4-(Dimethylamino)phenyl)indolizin-7-yl)ethan-1-one (17). To a solution of compound 15 $(0.11 \mathrm{~g}, 0.35 \mathrm{mmol})$ in dry THF $(3.5 \mathrm{~mL})$, under an argon atmosphere, a solution of methylmagnesium bromide in diethyl ether $\left(\mathrm{CH}_{3} \mathrm{MgBr} ; 0.35 \mathrm{~mL}, 3.0 \mathrm{M}\right)$ was added dropwise at $0{ }^{\circ} \mathrm{C}$. The reaction mixture was stirred at $0{ }^{\circ} \mathrm{C}$ for $2 \mathrm{~h}$. After the reaction was complete, as indicated by TLC, the mixture was quenched with saturated $\mathrm{NH}_{4} \mathrm{Cl}$ (aq), and then extracted twice with EtOAc. The combined organic layers were dried over anhydrous $\mathrm{MgSO}_{4}$, filtered, and evaporated. Subsequent silica-gel flash column chromatography afforded 1-(3-(4-(dimethylamino)phenyl)indolizin-7-yl)ethan-1-one (17) $(78 \mathrm{mg}, 0.28 \mathrm{mmol}$, $81 \%, R_{f}=0.26($ EtOAc/hexane $\left.=1: 3)\right)$ as a yellow solid. ${ }^{1} \mathrm{H}$ NMR $\left(500 \mathrm{MHz}, \mathrm{CDCl}_{3}\right) \delta$ (ppm): $8.16(\mathrm{~d}, J=8.0 \mathrm{~Hz}, 1 \mathrm{H}), 8.08(\mathrm{~d}, J=1.0 \mathrm{~Hz}, 1 \mathrm{H}), 7.44(\mathrm{~d}, J=8.5 \mathrm{~Hz}, 2 \mathrm{H}), 7.07(\mathrm{dd}$, 
$J=7.0,1.5 \mathrm{~Hz}, 1 \mathrm{H}), 6.88(\mathrm{~d}, J=4.0 \mathrm{~Hz}, 1 \mathrm{H}), 6.85(\mathrm{~d}, J=5.5 \mathrm{~Hz}, 2 \mathrm{H}), 6.83(\mathrm{~s}, 1 \mathrm{H}), 3.03(\mathrm{~s}, 6 \mathrm{H})$, 2.58 (s, 3H). ${ }^{13} \mathrm{C}$ NMR $\left(125 \mathrm{MHz}, \mathrm{CDCl}_{3}\right) \delta$ (ppm): 195.6, 150.1, 131.4, 129.6, 129.2, 125.2, 123.4, 121.6, 119.1, 115.4, 112.5, 108.1, 106.4, 40.4, 25.6. HRMS (ESI +): calcd for $\mathrm{C}_{18} \mathrm{H}_{19} \mathrm{~N}_{2} \mathrm{O}^{+}$ $[\mathrm{M}+\mathrm{H}]^{+}$279.1497, found 279.1492.

\section{Conclusions}

In summary, a novel 3,7-disubstituted indolizine-based fluorophore, whose emission wavelengths were tunable to cover a wide color range from blue to red-orange $(462-580 \mathrm{~nm})$, was designed and synthesized through a straightforward synthetic scheme starting from the pyrrole ring. Most of the functional groups introduced into the aryl ring at the C-3 position of indolizine did not induce changes in the photophysical properties, such as the absorption and emission wavelength. However, compound 9 bearing an $N, N$-dimethylamino group at the aryl ring exhibited a pronounced red-shift emission spectra $(533 \mathrm{~nm})$, compared to the other compounds (462-492 nm). This result was caused by the ICT process between the $\mathrm{N}, \mathrm{N}$-dimethylamino group and the ester group at the C-7 position in the indolizine scaffold. Furthermore, indolizine-based fluorophores showed more evident red-shift emission spectra $(580 \mathrm{~nm})$ through strengthening the ICT process by the introduction of more electron-withdrawing groups than the ester group, finally successfully leading to the potential fluorescent $\mathrm{pH}$ probe. Unfortunately, these newly developed indolizine fluorophores show broad emission spectra, which can cause fluorescent cross-talk problems [40-42]. In addition, they have absorption wavelengths in the UV and blue light range $(\sim 400 \mathrm{~nm})$. UV and blue light range possess higher energy than visible light $(>400 \mathrm{~nm})$, can be more damaging to the live cell, and usually cause high scattering more than other color light, which occasionally leads to a lower bioavailability [43]. Despite these drawbacks, many other advantages, such as easy access for absorption and emission tunability and predictability guided by computational studies, have rendered indolizine-based fluorophores versatile tools to generate fluorescent and fluorogenic probes. The past decade has witnessed remarkable advances in the development of new indolizine-based fluorophores. Thus, we are sure that our indolizine-based fluorophores could act as the new molecular template for the development of fluorophores with better photophysical properties and fluorescent probes, which leads to providing convenience for live-cell imaging. The following study will be reported in due course.

Supplementary Materials: The following are available online, Figure S1. Absorption and Emission Spectra of Compounds, Figure S2. ${ }^{1} \mathrm{H}$ and ${ }^{13} \mathrm{C}$ NMR Spectra.

Author Contributions: T.K. and J.K. conceived and designed the project. T.K. performed all experiments. T.K. and J.K. analyzed the data. T.K. and J.K. wrote the manuscript. All authors have read and agreed to the published version of the manuscript.

Funding: This work was supported by the Soongsil University Research Fund (New Professor Support Research) of 2019.

Institutional Review Board Statement: Not applicable.

Informed Consent Statement: Not applicable.

Data Availability Statement: The data presented in this study are available in supplementary materials.

Conflicts of Interest: The authors declare no conflicts of interest.

Sample Availability: Not available.

\section{References}

1. Fernández-Suárez, M.; Ting, A.Y. Fluorescent probes for super-resolution imaging in living cells. Nat. Rev. Mol. Cell Biol. 2008, 9, 929-943. [CrossRef] [PubMed]

2. Dean, K.M.; Palmer, A.E. Advances in fluorescence labeling strategies for dynamic cellular imaging. Nat. Chem. Biol. 2014, 10, 512-523. [CrossRef] 
3. Lavis, L.D.; Raines, R.T. Bright ideas for chemical biology. ACS Chem. Biol. 2008, 3, 142-155. [CrossRef]

4. Lukinavicius, G.; Umezawa, K.; Olivier, N.; Honigmann, A.; Yang, G.Y.; Plass, T.; Mueller, V.; Reymond, L.; Correa, I.R.; Luo, Z.G.; et al. A near-infrared fluorophore for live-cell super-resolution microscopy of cellular proteins. Nat. Chem. 2013, 5, 132-139. [CrossRef] [PubMed]

5. Uno, S.N.; Kamiya, M.; Yoshihara, T.; Sugawara, K.; Okabe, K.; Tarhan, M.C.; Fujita, H.; Funatsu, T.; Okada, Y.; Tobita, S.; et al. A spontaneously blinking fluorophore based on intramolecular spirocyclization for live-cell super-resolution imaging. Nat. Chem. 2014, 6, 681-689. [CrossRef] [PubMed]

6. Kobayashi, H.; Ogawa, M.; Alford, R.; Choyke, P.L.; Urano, Y. New strategies for fluorescent probe design in medical diagnostic imaging. Chem. Rev. 2010, 110, 2620-2640. [CrossRef]

7. Yun, S.W.; Kang, N.Y.; Park, S.J.; Ha, H.H.; Kim, Y.K.; Lee, J.S.; Chang, Y.T. Diversity oriented fluorescence library approach (DOFLA) for live cell imaging probe development. Acc. Chem. Res. 2014, 47, 1277-1286. [CrossRef]

8. Kwon, H.Y.; Liu, X.; Choi, E.G.; Lee, J.Y.; Choi, S.Y.; Kim, J.Y.; Wang, L.; Park, S.J.; Kim, B.; Lee, Y.A.; et al. Development of a universal fluorescent probe for gram-positive bacteria. Angew. Chem. Int. Ed. 2019, 58, 8426-8431. [CrossRef]

9. Vendrell, M.; Zhai, D.; Er, J.C.; Chang, Y.T. Combinatorial strategies in fluorescent probe development. Chem. Rev. 2012, 112, 4391-4420. [CrossRef]

10. Schiedel, M.S.; Briehn, C.A.; Bauerle, P. Single-compound libraries of organic materials: Parallel synthesis and screening of fluorescent dyes. Angew. Chem. Int. Ed. 2001, 40,4677-4680. [CrossRef]

11. Loudet, A.; Burgess, K. BODIPY dyes and their derivatives: Syntheses and spectroscopic properties. Chem. Rev. 2007, 107, 4891-4932. [CrossRef]

12. Boens, N.; Verbelen, B.; Dehaen, W. Postfunctionalization of the BODIPY core: Synthesis and spectroscopy. Eur. J. Org. Chem. 2015, 2015, 6577-6595. [CrossRef]

13. Choi, S.K.; Kim, J.; Kim, E. Overview of syntheses and molecular-design strategies for tetrazine-based fluorogenic probes. Molecules 2021, 26, 1868-1883. [CrossRef] [PubMed]

14. Cheema, H.; Baumann, A.; Loya, E.K.; Brogdon, P.; McNamara, L.E.; Carpenter, C.A.; Hammer, N.I.; Mathew, S.; Risko, C.; Delcamp, J.H. Near-infrared-absorbing indolizine-porphyrin push-pull dye for dye-sensitized solar cells. ACS Appl. Mater. Interfaces 2019, 11, 16474-16489. [CrossRef]

15. Gayton, J.; Autry, S.A.; Meador, W.; Parkin, S.R.; Hill, G.A.; Hammer, N.I.; Delcamp, J.H. Indolizine-cyanine dyes: Near infrared emissive cyanine dyes with increased stokes shifts. J. Org. Chem. 2019, 84, 687-697. [CrossRef]

16. Ji, R.X.; Liu, A.K.; Shen, S.L.; Cao, X.Q.; Li, F.; Ge, Y.Q. An indolizine-rhodamine based FRET fluorescence sensor for highly sensitive and selective detection of $\mathrm{Hg}^{2+}$ in living cells. RSC Adv. 2017, 7, 40829-40833. [CrossRef]

17. Park, J.; Lim, B.; Lee, N.K.; Lee, J.H.; Jang, K.; Kang, S.W.; Kim, S.; Kim, I.; Hwang, H.; Lee, J. Dual-functioning IQ-LVs as lysosomal viscosity probes with red-shifted emission and inhibitors of autophagic flux. Sens. Actuators B Chem. 2020, 309,127764 [CrossRef]

18. Park, S.; Kwon, D.I.; Lee, J.; Kim, I. When indolizine meets quinoline: Diversity-oriented synthesis of new polyheterocycles and their optical properties. ACS Comb. Sci. 2015, 17, 459-469. [CrossRef]

19. Albaladejo, M.J.; Gonzalez-Soria, M.J.; Alonso, F. Metal-free remote-site C-H alkenylation: Regio and diastereoselective synthesis of solvatochromic dyes. Green Chem. 2018, 20, 701-712. [CrossRef]

20. Sokolova, E.A.; Festa, A.A.; Subramani, K.; Rybakov, V.B.; Varlamov, A.V.; Voskressensky, L.G.; Van der Eycken, E.V. Microwaveassisted synthesis of fluorescent pyrido[2,3-b]indolizines from alkylpyridinium salts and enaminones. Molecules 2020, 25, 4059-4070. [CrossRef]

21. Kim, E.; Koh, M.; Lim, B.J.; Park, S.B. Emission wavelength prediction of a full-color-tunable fluorescent core skeleton, 9-aryl-1,2dihydropyrrolo[3,4-b]indolizin-3-one. J. Am. Chem. Soc. 2011, 133, 6642-6649. [CrossRef] [PubMed]

22. Choi, E.J.; Kim, E.; Lee, Y.; Jo, A.; Park, S.B. Rational perturbation of the fluorescence quantum yield in emission-tunable and predictable fluorophores (Seoul-Fluors) by a facile synthetic method involving C-H activation. Angew. Chem. Int. Ed. 2014, 53, 1346-1350. [CrossRef]

23. Kim, E.; Lee, Y.; Lee, S.; Park, S.B. Discovery, understanding, and bioapplication of organic fluorophore: A case study with an indolizine-based novel fluorophore, Seoul-Fluor. Acc. Chem. Res. 2015, 48, 538-547. [CrossRef] [PubMed]

24. Lee, Y.; Jo, A.; Park, S.B. Rational improvement of molar absorptivity guided by oscillator strength: A case study with furoindolizine-based core skeleton. Angew. Chem. Int. Ed. 2015, 54, 15689-15693. [CrossRef] [PubMed]

25. Choi, S.K.; Rho, J.; Yoon, S.E.; Seok, J.H.; Kim, H.; Min, J.; Yoon, W.; Lee, S.; Yun, H.; Kwon, O.P.; et al. Full color tunable aggregation-induced emission luminogen for bioimaging based on an indolizine molecular framework. Bioconjug. Chem. 2020, 31, 2522-2532. [CrossRef] [PubMed]

26. Choi, S.K.; Lee, Y.; Yoon, S.E.; Choi, H.; Kim, J.; Kim, J.H.; Lee, S.; Kim, W.; Kim, E. A tetrazine-fused aggregation induced emission luminogen for bioorthogonal fluorogenic bioprobe. Sens. Actuators B Chem. 2021, 340, 129966. [CrossRef]

27. Kucukdisli, M.; Opatz, T. A modular synthesis of polysubstituted indolizines. Eur. J. Org. Chem. 2012, 2012, 4555-4564. [CrossRef]

28. Bonte, S.; Ghinea, I.O.; Dinica, R.; Baussanne, I.; Demeunynck, M. Investigation of the pyridinium ylide-alkyne cycloaddition as a fluorogenic coupling reaction. Molecules 2016, 21, 332-346. [CrossRef]

29. Douglas, T.; Pordea, A.; Dowden, J. Iron-catalyzed indolizine synthesis from pyridines, diazo compounds, and alkynes. Org. Lett. 2017, 19, 6396-6399. [CrossRef] 
30. Sadowski, B.; Klajn, J.; Gryko, D.T. Recent advances in the synthesis of indolizines and their $\pi$-expanded analogues. Org. Biomol. Chem. 2016, 14, 7804-7828. [CrossRef]

31. Liu, B.; Wang, Z.; Wu, N.J.; Li, M.L.; You, J.S.; Lan, J.B. Discovery of a full-color-tunable fluorescent core framework through direct C-H (Hetero)arylation of N-Heterocycles. Chemistry 2012, 18, 1599-1603. [CrossRef]

32. de Silva, A.P.; Gunaratne, H.Q.; Gunnlaugsson, T.; Huxley, A.J.; McCoy, C.P.; Rademacher, J.T.; Rice, T.E. Signaling recognition events with fluorescent sensors and switches. Chem. Rev. 1997, 97, 1515-1566. [CrossRef]

33. Badone, D.; Baroni, M.; Cardamone, R.; Ielmini, A.; Guzzi, U. Highly efficient palladium-catalyzed boronic acid coupling reactions in water: Scope and limitations. J. Org. Chem. 1997, 62, 7170-7173. [CrossRef] [PubMed]

34. Grabowski, Z.R.; Rotkiewicz, K.; Rettig, W. Structural changes accompanying intramolecular electron transfer: Focus on twisted intramolecular charge-transfer states and structures. Chem. Rev. 2003, 103, 3899-4032. [CrossRef]

35. Reichardt, C. Solvatochromic dyes as solvent polarity indicators. Chem. Rev. 1994, 94, 2319-2358. [CrossRef]

36. He, L.; Dong, B.; Liu, Y.; Lin, W. Fluorescent chemosensors manipulated by dual/triple interplaying sensing mechanisms. Chem. Soc. Rev. 2016, 45, 6449-6461. [CrossRef]

37. Tang, Y.; Kong, X.; Xu, A.; Dong, B.; Lin, W. Development of a two-photon fluorescent probe for imaging of endogenous formaldehyde in living tissues. Angew. Chem. Int. Ed. 2016, 55, 3356-3359. [CrossRef] [PubMed]

38. Hossain, S.M.; Singh, K.; Lakma, A.; Pradhan, R.N.; Singh, A.K. A schiff base ligand of coumarin derivative as an ICT-Based fluorescence chemosensor for $\mathrm{Al}^{3+}$. Sens. Actuators B Chem. 2017, 239, 1109-1117. [CrossRef]

39. Jiang, C.; Huang, H.; Kang, X.; Yang, L.; Xi, Z.; Sun, H.; Pluth, M.D.; Yi, L. NBD-based synthetic probes for sensing small molecules and proteins: Design, sensing mechanisms and biological applications. Chem. Soc. Rev. 2021, 50, 7436-7495. [CrossRef]

40. Wu, X.; Sun, X.; Guo, Z.; Tang, J.; Shen, Y.; James, T.D.; Tian, H.; Zhu, W. In vivo and in situ tracking cancer chemotherapy by highly photostable NIR fluorescent theranostic prodrug. J. Am. Chem. Soc. 2014, 136, 3579-3588. [CrossRef]

41. Araneda, J.F.; Piers, W.E.; Heyne, B.; Parvez, M.; McDonald, R. High Stokes shift anilido-pyridine boron difluoride dyes. Angew. Chem. Int. Ed. 2011, 50, 12214-12217. [CrossRef] [PubMed]

42. Shcherbakova, D.M.; Hink, M.A.; Joosen, L.; Gadella, T.W.; Verkhusha, V.V. An orange fluorescent protein with a large Stokes shift for single-excitation multicolor FCCS and FRET imaging. J. Am. Chem. Soc. 2012, 134, 7913-7923. [CrossRef] [PubMed]

43. Oliveira, E.; Bertolo, E.; Nunez, C.; Pilla, V.; Santos, H.M.; Fernandez-Lodeiro, J.; Fernandez-Lodeiro, A.; Djafari, J.; Capelo, J.L.; Lodeiro, C. Green and Red Fluorescent Dyes for Translational Applications in Imaging and Sensing Analytes: A Dual-Color Flag. ChemistryOpen 2018, 7, 9-52. [CrossRef] [PubMed] 